\title{
THE EVOLUTION OF THE EU LAW AGAINST CRIMINAL FINANCE: THE "HARDENING" OF FATF STANDARDS WITHIN THE EU
}

\author{
Leonardo Borlini* And Francesco Montanaro**
}

\begin{abstract}
This Article examines the recent evolution of the EU anti-money-laundering (AML) and counter-terrorist financing (CTF) legislative framework, focusing on the relationship between the main international standards in the field and the newest EU legislation. It suggests that international soft law norms-in particular, the Financial Action Task Force (FATF) Recommendations-have had a decisive influence on the latest development of legislation at the EU level and within its member states. It further argues that mainly the preventive component of the AML/CTF legislation will be strengthened by the EU instruments adopted in mid-2015. However, this Article concludes that the adoption of global soft standards has posed significant challenges to the EU legislative framework. The arguments are developed in four parts. The Article first highlights the main regulatory prescriptions that stem from the study of the phenomenology and the economics of AML/CTF regulation and underpin the current international regulatory paradigm. Second, it explores the evolution of the main international instruments in the field with a special focus on the role played by the FATF Recommendations. It also illustrates the relation between these instruments and the adoption of the new EU AML/CTF legislation from two different, but complementary, angles: (1) noting that the current international AML/CTF framework has a multidisciplinary approach, the Article focuses on the framework's repressive component and assessing the limits of the EU criminal approach against money laundering and terrorist financing; and (2) examining the recent EU preventive legislation and addressing the main challenges posed to the EU legislative framework when attempting to accommo-
\end{abstract}

* Assistant Professor, Università Bocconi, Milan. Dr. Borlini presented an earlier version of the present paper at the ASIL Annual Conference, International Economic Law Interest Group, Biannual Conference, held at the Georgetown University Law Center in Washington, D.C. (United States) on September 30, 2016-October 1, 2016. We thank the discussants and all the participants for their helpful comments. Part IV and Sections C, D and E of Part V elaborate on and expand Leonardo Borlini, Regulating Criminal Finance in the EU in the Light of the International Instruments, 36 Y.B. Eur. L. 1 (2017). This Article is a joint effort of the authors. However, Parts I and II, and Sections A, D, and E of Part V were written by Leonardo Borlini, whilst Parts III and IV, and Sections B, and C of Part V were written by Francesco Montanaro. (C) 2017, Leonardo Borlini and Francesco Montanaro.

** Post-doctoral researcher, Erasmus University Rotterdam. 
date global standards, especially regarding tensions with fundamental freedoms and human rights protected within the EU.

I. InTRODUCTION . . . . . . . . . . . . . . . . . . . . . . . . 1011

II. Phenomenology of Criminal Finance: Regulatory

IMPLICATIONS . . . . . . . . . . . . . . . . . . . . . . . . . . . . . 1014

A. Globalization and the Burgeoning of Criminal Finance . . . 1014

B. The Emergence of a Comprehensive Approach to Fight Money

Laundering . . . . . . . . . . . . . . . . . . . . 1015

C. The Interplay between AML and CTF Strategies . . . . . . . 1017

D. Economic Rationales of AML/CTF Disciplines . . . . . . . . 1018

E. Economic Arguments Supporting International

Cooperation. . . . . . . . . . . . . . . . . . . . 1020

F. Drawing Some Lessons for a Comprehensive AML/CTF

Regulation . . . . . . . . . . . . . . . . . . . 1022

III. The International AML/CTF Regulatory Framework . . . . 1023

A. The Evolution of AML/CTF Law . . . . . . . . . . . . . . 1023

B. The FATF: A "Soft" International Organization . . . . . . . . 1023

C. The "Hard" Impact of Global "Soft" Instruments. . . . . . . 1026

IV. InCorporating International Criminalization Standards

in EU Money Laundering and Terrorist Financing

LeGISLATION . . . . . . . . . . . . . . . . . . . . . . . . . . 1030

A. The Prohibition of AML in EU Secondary Legislation . . . . 1030

B. The Definition of Money Laundering and Terrorist

Financing under EU Law. . . . . . . . . . . . . . . . . 1031

C. Criminalizing Laundering Crimes at the European Level? . . . . . 1033

D. Forward-looking Remarks . . . . . . . . . . . . . . . . 1035

V. The Reform of the EU Framework on the Prevention of

Money Laundering and Terrorist Financing . . . . . . . . . 1036

A. The New EU AML/CTF Preventive Framework . . . . . . . . 1036

B. Enlarging the Scope of the Directive . . . . . . . . . . . . . 1037

C. Increasing Effectiveness: The Public-Private Partnership and the Strengthened RBA. . . . . . . . . . . . . . . . . . . 1039

D. Towards Greater Effectiveness and Transparency . . . . . . . 1042

E. The Balance with Protection of Fundamental Freedoms and Rights: The Emergence of a European Interest in an Effective AML/CTF Law. . . . . . . . . . . . . . . . . . . . . . . 1043

F. The Uneasy Relationship between AML/CTF Law, the Right to Privacy, and Data Protection Law . . . . . . . . . . . . . . 1049

1. The Protection of the Right to Privacy and the Protection of Personal Data under International Law and EU Law . . . . . . . . . . . . . . . . . . 1049 
2. The Remaining Tensions between AML/CTF

Law, the Right to Privacy, and Data Protection

Law. . . . . . . . . . . . . . . . . . . . . . . 1051

VI. Conclusion . . . . . . . . . . . . . . . . . . 1059

\section{INTRODUCTION}

The Financial Action Task Force (FATF) has been key to developing a body of soft rules on anti-money-laundering and counter-terrorist financing (AML/CTF). Soft law instruments have generally been considered more suitable for regulating such matters because nations are generally wary of undertaking excessively stringent commitments. ${ }^{1}$ Moreover, soft law instruments are characterized by a sufficient degree of flexibility that allows prompt adaptation to changing regulatory needs. ${ }^{2}$ This kind of flexibility and openness to change is particularly important in a field where domestic laws and regulations, as well as enforcement actions, have to keep pace with money launderers and terrorist financiers to remain effective. ${ }^{3}$ The soft nature ${ }^{4}$ of the FATF Recommendations allows constant updating thereof, as well as the participation of non-state actors, such as banks and other financial institutions. ${ }^{5}$

1. Luigi Condorelli, Diritto e non diritto nella CSCE, in LA NuOva Europa Della CSCE 47, 62 (Giovanni Barberini \& Natalino Ronzitti eds., 1994).

2. The phrase "soft law" generally comprises "all those social rules generated by State[s] or other subjects of international law which are not legally binding but which are nevertheless of special legal relevance." Daniel Thürer, Soft Law, in MAx Planck Encyclopedia of Public INTERNATIONAL LAW 271 (Rüdiger Wolfrum ed., 2013). Legal scholarship has extensively investigated the relevance of soft law instruments in the context of international relations. See Jaye Ellis, Shades of Grey: Soft Law and the Validity of Public International Law, 25 LEIDEN J. INT'L L. 313 (2012); Prosper Weil, Towards Relative Normativity in International Law?, 77 AM. J. INT'L L. 143 (1983); Kenneth W. Abbott \& Duncan Snidal, Hard and Soft Law in International Governance, 54 InT'L Org. $421(2000)$.

3. It has been noted that "the form of Recommendations appropriately reflects the evolving character of the conduct that they address." Cecily Rose, International ANTi-Corruption Norms: Their Creation and Influence on Domestic Legal Systems 192 (2015).

4. See Tullio Treves, International Law: Achievements and Challenges, in $\mathrm{X}$ Cursos Euromediterráneos Bancaja de Derecho Internacional 139 (2006); Martti Koskenniemi, The Fate of Public International Law: Between Technique and Politics, 70 MoD. L. Rev. 1, 4-15 (2007); Anne Peters, Soft Law as a New Mode of Governance, in The Dynamic of Change In EU Governance 31-32 (Udo Diedrichs, Wulf Reiners \& Wolfgang Wessesls eds., 2011). With reference to the FATF, see Stavros Gadinis, Three Pathways to Global Standards: Private, Regulation, and Ministry Networks, 109 AM. J. INT'L L. 1 (2015).

5. See Rose, supra note 3, at 195. 
Moreover, the emergence of a body of AML soft rules is an illustration of the growing tendency towards specialization and fragmentation of international law, ${ }^{6}$ as well as an illustration of the role that soft law may play in developing international technical regulation. The high level of detail, based on economic models, which inspires and shapes the current AML/CTF legal framework finds its first and natural "body" in a soft law instrument (such as the FATF Recommendations) adopted by a technocratic body (like the FATF) and thereafter-and only thereafter-could be translated into binding international legal instruments.

The interconnectedness of financial markets has favored the widespread diffusion of such standards. States have generally attempted to comply with them in order to gain legitimacy and maintain access to financial markets. ${ }^{7}$ However, the FATF has generally acted as a "singleminded" body with a single and overriding objective. ${ }^{8}$ This "monodimensional" approach, however, has often failed to pay sufficient heed to a number of legitimate concerns, not least the protection of fundamental rights, such as the right to privacy and the right to protect personal data. ${ }^{9}$ Consequently, domestic measures implementing FATF standards may often impinge on such rights. The EU legal system constitutes an ideal vantage point to look into this tussle. For one thing, the EU and its member states have actively participated in the development of international and regional instruments from the inception of the efforts to combat money laundering and terrorist financing. ${ }^{10}$ Secondary EU legislation has generally incorporated in full the content of FATF Recommendations. Since the adoption in 1991 of the First

6. Legal scholarship has investigated at length this tendency. See, e.g., Andreas FischerLescano \& Gunther Teubner, Regime-Collisions: The Vain Search for Legal Unity in the Fragmentation of Global Law, 25 Mich. J. INT'L L. 999 (2004); Koskenniemi, supra note 4, at 5-9.

7. See generally J. C. Sharman, The Money Laundry: Regulating Criminal Finance in the Global ECONOMY (2011).

8. Valsamis Mitsilegas \& Niovi Vavoula, The Evolving EU Anti-Money Laundering RegimeChallenges for Fundamental Rights and The Rule of Law, 23 MaAstricht J. Eur. \& Comp. L. 261, 292-293 (2016).

9. Leonardo Borlini, Regulating Criminal Finance in the EU in the Light of the International Instruments, Y.B. EUR. L. 1, 41 (2017).

10. See, e.g., Fin. Action Task Force, Int'L Standards on Combating Money Laundering and the Financing of Terrorism and Proliferation (2016) (ebook) [hereinafter FATF Recommendations]; see also Eleni Tsingou, Money Laundering, in Europe AND THE Governance of Global FinANCE 151 (Daniel Mügge ed., 2014). 
European Commission (EC) Anti-Money-Laundering Directive, ${ }^{11}$ EU money laundering (ML) and, later, terrorist financing (TF) countermeasures have closely reflected international developments. Having said that, when exercising its legislative power, the EU is required to comply with the fundamental rights protected under EU law. Since its seminal judgment in Internationale Handelsgesellschaft ${ }^{12}$ in 1970, the European Court of Justice has considered fundamental rights as general principles of the EU legal system. Subsequently, after the entry into force of the Treaty of Lisbon, the Charter of Fundamental Rights of the European Union has eventually acquired EU primary law status. Whether, however, the EU legislation in this field is always consistent with such rights is not entirely sure.

This Article investigates the evolution of AML/CTF soft law and its implementation in the EU legal system. Bearing this in mind, it then considers how EU AML/CTF legislation interacts with the protection of fundamental rights and, especially, the rights to privacy and the rights to data protection. In Section II, it discusses the main regulatory prescriptions that stem from the study of the phenomenology and economics of regulation of money laundering and terrorism financing underpinning the current international anti-money-laundering and counter-terrorist financing law. In Section III, it outlines the central role played by the FATF Recommendations in the evolution of international initiatives in the field. Notably, it illustrates that the EU AML/ CTF legislation is modelled on the Recommendations and features an articulated multidisciplinary approach. In Section IV, it deals with the repressive component of such a legislative framework and assesses the limits of the EU criminal approach against laundering and terrorism financing crimes. Section $\mathrm{V}$ focuses on the challenges posed to the $\mathrm{EU}$ legislative framework when accommodating global standards, especially with regard to possible tensions with fundamental freedoms and human rights. In particular, it explores the complex interplay between, on the one hand, AML/CTF measures and, on the other hand, the right to fair trial, the protection of personal data, and the right to privacy.

11. Council Directive 91/308/EEC, of 10 June 1991, Prevention and Use of the Financial System for the Purpose of Money Laundering, 1991 O.J. (L 166) 77 [hereinafter First AML Directive].

12. Case $11 / 70$, Internationale Handelsgesellschaft mbH v. Einfuhr- und Vorratsstelle für Getrreide, 1970 E.C.R. 1125. 


\section{Phenomenology of Criminal Finance: Regulatory Implications}

This Section delves into the regulatory response to criminal finance. Section A explains how the integration of financial markets opened the way to the proliferation of criminal finance. Sections B and C outline the characteristics of the existing international legal framework applicable to criminal finance and the interaction among rules on AML and CTF strategies. Finally, Sections D and E analyze the economic rationales justifying the regulatory intervention and international cooperation in this field.

\section{A. Globalization and the Burgeoning of Criminal Finance}

The increasing deregulation and integration of financial markets, along with unprecedented technologic progress, have contributed to the burgeoning of criminal finance over the past thirty years. ${ }^{13}$ Due to the combination of these factors, the number of cross-border financial transactions has increased at a striking pace. Nowadays, businesses' faceless employees can transfer huge amounts of money from one corner of the world to another with a mere click of the mouse. ${ }^{14}$ Also, a variety of financial instruments-over-the-counter derivatives, international mortgages, and bank-to-bank loans-may facilitate the perpetration of illegal conduct. Against this background, domestic regulatory and enforcement authorities often fall short of tackling a crime, which often has a cross-border dimension. Not surprisingly, businesses and habitual money launderers have little difficulty in taking advantage of loopholes among national jurisdictions. It is thus evident that international cooperation and, notably, the adoption of international instruments play a crucial role in fighting all such crimes. ${ }^{15}$

13. See Mark Pieth, International Standards against Money Laundering, in A ComPARATIVE GUIDE to Anti-Money Laundering: A Critical Analysis of Systems in Singapore, Switzerland, the UK AND THE USA 5 (Mark Pieth \& Gemma Aiolfi eds., 2004).

14. See Cyrille Fijnaut, Transnational Crime and the Role of the United Nations in Its Containment through International Cooperation: A Challenge for the 21st Century, 8 EUR. J. CRIME CRIM. L. \& CRIM. Just. 119 (2000).

15. See, e.g., Valsamis Mitsilegas, Money Laundering Counter-Measures in the European Union: A New Paradigm of Security Governance Versus fundamental Legal Principles 18 (2003); William C. Gilmore, Dirty Money: The Evolution of International Measures to Counter Money Laundering AND the Financing OF TERrorism 13 (2004). 


\section{B. The Emergence of a Comprehensive Approach to Fight Money Laundering}

The need to devise a global strategy to target the proceeds of profit-generating criminal offenses translated into a combination of global "hard law" treaty instruments and "soft law" standards, elaborated within the confines of the FATF. Hard law treaties were mainly negotiated under the auspices of the United Nations. Notably, the U.N. Convention against Illicit Traffic in Narcotic Drugs and Psychotropic Substances of 1988, the U.N. Convention against Transnational Organized Crime (UNCTOC) and its protocols, and the U.N. Convention against Corruption (UNCAC) all contain analytical provisions to prevent and repress money laundering, as well as terrorist financing. ${ }^{16}$ In addition, a number of regional treaties target the crimes at issue (e.g., the 2005 Council of Europe Convention against money laundering and terrorist financing). ${ }^{17}$ After the $9 / 11$ terrorist attacks, the U.N. Security Council designed its response to Islamic terrorism by adopting a broader conception of the principle "follow the money". ${ }^{18}$

16. See, e.g., United Nations Convention against Transnational Organized Crime art. 6, Nov. 15, 2000, 2225 U.N.T.S. 209; United Nations Convention against Corruption art. 14, Oct. 31, 2003, 2349 U.N.T.S. 41.

17. See supra Section II.A.

18. As is widely known, after $9 / 11$, the U.N. went beyond its conventional approach to terrorism and adopted Security Council Resolutions that add complexity to the existing legal framework. Therefore, after the adoption of the 1999 International Convention for the Suppression of Financing of Terrorism, the Security Council became the focal point of discussions and the forum for the adoption of measures against terrorism. Significantly, in subsequent resolutions, it stressed the importance of terrorist financing, obliging states to implement specific measures in identifying and freezing terrorist-related funds. These novel measures underscored the inadequacy of domestic and international financial systems in dealing with terrorist funds, although the problem was not unknown. Furthermore, they exposed a lack of intra-state coordination and coordination among states, intergovernmental organizations, and private financial institutions. Security Council Resolution 1373/2001 stated that all "States should prevent and suppress the financing of terrorism, as well as criminalize the wilful provision or collection of funds for such acts. The funds, financial assets and economic resources of those who commit or attempt to commit terrorist acts or participate in or facilitate the commission of terrorist acts and of persons and entities acting on behalf of terrorists should also be frozen without delay." The Security Council also decided that "States should prohibit their nationals or persons or entities in their territories from making funds, financial assets, economic resources, financial or other related services available to persons who commit or attempt to commit, facilitate or participate in the commission of terrorist acts." In short, the obligations of the 1999 Convention were substantially reproduced in Resolution 1373 of 2001 so that the U.N. member states were expected to comply with the obligations of the Convention, without taking into account whether they had ratified it or not. See S.C. Res. 1373, II 6 (Sept. 28, 2001). 
On the other hand, soft law greatly influenced the international legal framework against criminal finance. The FATF Recommendations constitute the universal standards for AML/CTF domestic legislation in the world. Although the Recommendations are a non-binding instrument, they have taken a quasi-binding character because of the large membership of the FATF-which includes virtually all developed and several emerging countries-and the sanctions mechanism ensuring their implementation. ${ }^{19}$ Moreover, the reproduction of several of its provisions in a wide variety of international "hard" instruments, as well as the explicit reference to these provisions made by some U.N. Security Council Resolutions against terrorism, also have contributed to increase the importance of such non-binding standards. ${ }^{20}$ In a 2005 , for example, the Security Council strongly urged all member states to implement the comprehensive, international standards embodied in the FATF Recommendations to tackle laundering crimes and terrorist financing. ${ }^{21}$ As is well known, AML countermeasures are absolutely key to fighting criminal organizations. A sound anti-organized-crime strategy should necessarily aim to tackle the complex corporate structures created by such criminal organizations. ${ }^{22}$

Although these organizations are more effective in their home countries, ${ }^{23}$ their ability and inclination to operate across national boundaries in order to maximize their profits is evident. The fact that financial capital "can move freely between countries has created new

19. Borlini, supra note 9 , at 14-15.

20. Id.

21. S.C. Res. 2255 (Dec. 21, 2015). The Security Council repeated this exhortation in December 2015. S.C. Res. 2253 (Dec. 17, 2015).

22. See William C. Gilmore, Money Laundering, in Routledge Handbook of Transnational Criminal Law 331-332 (Neil Boister \& Robert J. Currie eds., 2015); see also Sabrina Adamoli Et Al., ORGANISED CRIME AROUND THE WORLD 25 (1998).

23. See Europol, Threat Assessment: Italian Organized Crime 15 (2013) (remarking that infiltration in the legal economy through complex money-laundering techniques is one of the emerging and most dangerous trends of the Italian criminal organizations' lives: "[t]o quote a well-known Italian Public Prosecutor, 'Italian OCGs today are the only EU economic competitors that suffer the opposite problem of all other entrepreneurs: too much cash money and not enough possibilities of reinvestment.' This concept, combined with the on-going economic crisis, explains the recent trend towards infiltration in the legal economy: through sophisticated money laundering schemes and through careful investments in particular sectors, these groups not only attempt to justify their immense wealth, but present themselves on the market as strong competitors who can afford to operate 'at a loss', creating in the long run a situation of quasi-monopoly that undermines the basic principles of free market"). 
ways for organized crime to disguise the origin of illegal proceeds". ${ }^{24}$ Developing a sophisticated treasury-type activity from simple trade finance was a significant step for criminal organizations and full-scale international money laundering an easy step thereafter. ${ }^{25}$

Removing the financial incentive to committing crime and reducing financial ability to perpetrate crimes-by tracing, freezing, and confiscating the proceeds of such crime-plays a major role in crime prevention. AML regulation has, therefore, become a cornerstone of a broader agenda to fight organized crime and other crimes, including corruption, by depriving criminals-both corrupt public officials and corruptors- of ill-gotten gains and by prosecuting those who assist in laundering these gains. ${ }^{26}$

\section{The Interplay between AML and CTF Strategies}

Money laundering and terrorist financing are characterized by rather opposing dynamics and objectives. The former aims to rub out the illicit origin of a given amount of money. Therefore, the rationale of AML legislation is to prevent criminals from enjoying the profits of their previous crimes (predicate crimes). Terrorist financing, instead, implies "money dirtying," which is the reverse of money laundering. ${ }^{27}$ That is to say, it diverts "clean money" into terrorist activities. ${ }^{28}$ Accordingly, the main concern of money launderers is to conceal the origin of the money, while terrorists generally seek to hide the funded activity. ${ }^{29}$

Notwithstanding their differences, international and domestic law instruments jointly deal with these crimes. This policy choice is often warranted by efficiency considerations. For one thing, the fight against these crimes entails a "horizontal strategy" embracing a wide variety of

24. Brigitte Unger, Money Laundering Regulation: From Al Capone to Al Qaeda, in ReSEARCH Handbook On Money Laundering 21 (Brigitte Unger \& Daan van der Linde eds., 2013).

25. Through money laundering, criminals may pollute the whole economic environment and, eventually, integrate themselves and their businesses within local societies: the case of the boss of the drug cartel of Medellin, Pablo Escobar Gaviria, who, at the apex of his power during the 1980s, volunteered to adjust the Colombian public debt, is just the most notorious example of such contamination. See Pietro Grasso \& Enrico Bellavia, Soldi sporchi: Come le mafie RICICLANO MILIARDI E INQUINANO L'ECONOMIA 11 (2011); see also EUROPOL, supra note 23, at 15.

26. See Louis de Koker \& Mark Turkington, Transnational Organised Crime and the Anti-Money Laundering Regime, in International LaW And Transnational Organized Crime 241 (Pierre Hauck \& Sven Peterke eds., 2016).

27. Unger, supra note 24 , at 21.

28. For example, in the guise of legal charity, donations may be moved to sponsor terrorist organizations.

29. Borlini, supra note 9 , at 4 . 
fields, including criminal law, administrative law, and public international law. ${ }^{30}$ Moreover, both crimes presuppose the deployment of financial institutions for illicit purposes and often adopt similar techniques. ${ }^{31}$ More importantly, money laundering may be instrumental in concealing the illegal origin and destination of funds directed to finance terrorist activities. ${ }^{32}$ Ultimately, combining AML and CTF strategies enables enforcement authorities to tackle both crimes in a more effective manner. ${ }^{33}$

\section{Economic Rationales of AML/CTF Disciplines}

Economists have conceived refined models to interpret and design AML/CTF regulation, distinguishing regulation in this field from regulation of other related issues like the economic and financial implications of money laundering, the scale of the crime, and the taxonomy of the techniques of laundering. ${ }^{34}$ The economics of AML/ CTF regulation aims at, simultaneously, justifying tax money spent on AML policies and orienting lawmakers so that they can shape accurate responses to money laundering and terrorist financing, pursuing both effectiveness and efficiency of AML regulation and enforcement. ${ }^{35}$

30. See John Vervaele, Economic Crimes and Money Laundering: A New Paradigm for the Criminal Justice System?, in RESEARCH HANDBOOK ON MONEy LAUNDERING, supra note 24, at 385-86.

31. See id.; Paul Allan Shcott, Reference Guide to Anti-Money Laundering and Combating THE FinanCing Of Terrorism I-5-I-10 (2d ed. Supp. 2006).

32. Unger, supra note 24 , at 20. The Taliban, for example, profited from the trafficking of opium and taxing the drug trade in areas under its control, and these funds were subsequently used to support terrorist organizations like Al Qaeda. See S.C. Res. 1333 (Dec. 19, 2000). According to the U.N. Office on Drugs and Crime, estimates of the income derived by the Taliban from taxes levied on opium production range from $\$ 15$ to $\$ 27$ million per annum. See Rep. of the Committee of Experts Appointed Pursuant to Security Council Resolution 1333 (2000), Paragraph 15(a), Regarding Monitoring of the Arms Embargo against the Taliban and the Closure of Terrorist Training Camps in the Taliban-held Areas of Afghanistan (2001), If 60, U.N. Doc. S/2001/511 (May 21, 2001). By the same token, the recent Resolution 2199/2015, adopted by the UN Security Council on 12 February 2015, also underscores the possibility that terrorism is financed by the proceeds of organized crime and drug trafficking. See S.C. Res. 2199 (Feb. 12, 2015).

33. See infra Section IV.

34. The literature on the economics of money laundering and on the indications that may be derived for an accurate AML policy has lately flourished. For a comprehensive study, see DoNATO Masciandaro, Elöd Takáts \& BrigitTe Unger, Black Finance: The Economics of Money LaunderING (2007). See also Research HANDBook on Money LaUndering, supra note 24 (referring to a wide literature).

35. Unger, supra note 24, 25-29. 
Analytical microeconomic models for more effective AML/CTF countermeasures have focused both on the demand and the supply side. For example, Donato Masciandaro's study first considers the demand side. ${ }^{36}$ The model assumes that a rational agent - a criminal actor or organization-deriving revenues from a criminal activity aims at maximizing the expected utility of the resulting criminal proceeds. ${ }^{37}$ The criminal/organization may or may not choose laundering. Game theory may help to identify the main determinants of money laundering and establish their relationship with the expected utility. The utility, in fact, increases with the average return expected from reinvestment-licit (investment) and/or illicit (re-accumulation) - of the laundered cash and decreases in relation to cost of laundering (typical transactional costs), probability of detection, and severity of punishment (also assumed as transactional costs). ${ }^{38}$

An economic analysis of the supply side is also relevant for designing effective countermeasures. The banking and financial sectors can play a crucial role in the development of criminal activities as vehicles for cleaning dirty money. The supply side of the money laundering market consists of regulatory agencies that are supposed to fight money laundering (the Authority) and financial intermediaries (the Bank or other financial institutions), which may or may not be honest and compliant with law and regulations. The typical market issues are asymmetric information and principal-agent problems. ${ }^{39}$ In other words, on the one hand, the Authority does not always possess full information about the financial intermediaries; on the other hand, financial intermediaries do not internalize the benefits of the enforcement of antimoney-laundering laws.

In defining an effective system of AML/CTF law, four elements should be carefully considered ${ }^{40}$ : (a) the difference in information assets between individual intermediaries and regulatory agencies, the market at hand being opaque by definition; (b) the non-verifiability of intermediaries' efforts to comply; (c) the cost of the latter for interme-

36. See Donato Masciandaro, Money Laundering: The Economics of Regulation, 7 EUR. J. L. \& ECON. 225 (1999).

37. Id. at $227-28$

38. Id. at 225-30.

39. See Lucia D. Pellegrina \& Donato Masciandaro, The Risk Based Approach in the New European Anti-Money Laundering Legislation: A Law and Economics View, 5 Rev. LAW \& ECON. 932 (2009); MARK Pieth \& Gemma Aiolfi, Anti-Money Laundering: Levelling the Playing Field (2003), https:/ / www. baselgovernance.org/sites/collective.localhost/files/publications/biog_working_paper_01.pdf.

40. See Pellegrina \& Masciandaro, supra note 39 , at 933-35. 
diaries; and (d) the non-verifiability of the influence of the effort on the performance of the regulation. The more specialized and financially educated the AML agency, the more efficient its actions. ${ }^{41}$ The above-mentioned model also underlines that efficient regulation of the supply side requires that regulators take the problem of compliance costs into due consideration. This model has two key bearings on AML/CTF regulation.

First, AML/CTF regulation should directly involve financial intermediaries and other professional categories in order to cope with the issue of asymmetric information and enhance the prevention of laundering crimes. These subjects, who have a tangible and direct contact with their clients, are better placed to detect potential suspicious activities. ${ }^{42}$ The private sector should perform a number of preventive measures (customer identification, customer due diligence notification of suspicious operations to the competent public authorities), together with compulsory network duties.

Second, the regulatory framework should be risk-based (the so-called risk-based approach [RBA]) in order to reduce compliance costs for the private sector. The goal of a risk-oriented AML regulation is to calibrate measures to risk, meaning that the highest money laundering or terrorist financing risks should receive maximum attention in terms of resource allocation in order to increase the regulatory outcome. ${ }^{43}$ This idea has another major implication for AML/CTF regulation: it shifts part of the responsibility for defining the risks and developing countermeasures, and above all, for dynamic risk-management, onto the private institutions and professionals involved. Taken together, these elements produce a regulatory model based on a public-private partnership.

\section{E. Economic Arguments Supporting International Cooperation}

Recent studies show how models of international economics and tax competition can be applied to money laundering issues. These works essentially represent variations of Tinbergen's model, which imports Newton's theory of gravity to economics to foresee trade flows among

41. See id.

42. See Antoinette Verhage, The Anti Money Laundering Complex and the Compliance INDUSTRY (2011).

43. See Fin. Action Task Force, fatf Guidance on the Risk-Based Approach to Combating Money Laundering and Terrorist Financing: High Level Principles and Procedures 2 (2007), http:/ /www.fatf-gafi.org/media/fatf/documents/reports/High\%20Level\%20Principles\%20and\% 20Procedures.pdf. 
countries. ${ }^{44}$ Applied to the money laundering context, this model gives a credible explanation of launderers' behavior. Newton's masses are replaced by the per capita GDP and the amount of crime and criminal proceeds, attractiveness indicators replace gravity, and the physical distance is augmented by cultural and economic distance. Thus, assuming that launderers behave as rational actors, they tend to invest their money in developed countries with low corruption and conflicts. In addition, launderers prefer easy and quick access as provided by countries that are members of the Society for Worldwide Interbank Financial Telecommunication (SWIFT). Obviously, they prefer to invest where it is possible to get high rates of return. But, contrary to the typical licit investor, they prefer countries with high bank secrecy and lax AML law. ${ }^{45}$ These patterns seem to be confirmed by the allocation of money laundering around the world: Unger's empirical research leads to the somewhat counterintuitive result that, globally, most of the top-twenty countries receiving money for laundering are well established, well developed, and quite sizeable-the major one being the United States. ${ }^{46}$ Money laundering is thus not restricted to small countries and tax havens; rather, it represents a serious problem for well-established industrialized countries endowed with functional financial markets like those in the EU.

Unger also questions whether it pays for countries to compete for criminal money, assuming that the underlying crime (e.g., drug trafficking) stays in the original country (e.g., Colombia) and only the proceeds of the predicate crime (e.g., the drug money) moves to welldeveloped economies (e.g., Europe and the United States). ${ }^{47}$ Tax competition models show that original welfare gains deriving from the additional criminal money can easily be lost when other countries adopt the same policy. ${ }^{48}$ This model assumes that countries can deliberately choose to "launder or not," an effective AML policy being adoptable at will. ${ }^{49}$

According to this model, successful financial markets can attract all kinds of investors, even criminals. Based on this assumption, money laundering can be interpreted as a typical externality also in interna-

44. See Jan Tinbergen, Shaping the World Economy: Suggestions for an International ECONOMiC POLICY (1962).

45. See Masciandaro, Takáts \& Unger, supra note 34 , at xii.

46. Id.

47. $I d$.

48. $I d$

49. Id. 
tional economics, with the effect that governments that do not internalize the harms of crime committed elsewhere might want to turn a blind eye to laundering operations of foreign money. Seen from this perspective, the case for international coordination of AML laws is compelling. States can avoid the non-cooperative equilibrium of the implied prisoner's dilemma only by reciprocally tying their hands.

\section{F. Drawing Some Lessons for a Comprehensive AML/CTF Regulation}

The study of the phenomenology of money laundering and terrorist financing and the economics of their regulation bears important regulatory implications. First, the opportunities offered to criminals, launderers, and terrorists by globalization, the frequent transnational dimension of laundering crimes, along with the risks of non-cooperative equilibrium highlighted by international economic models, suggest that an effective AML/CTF normative response is to be developed through the highest possible level of international coordination among states. ${ }^{50}$

Second, AML and CTF strategies converge: they aim at attacking the criminal or terrorist organization through its financial activities and use the financial trails to identify the various components of the criminal or terrorist network. In both cases, investigations mainly target financial institutions through which criminal and terroristic groups move and deploy their resources. ${ }^{51}$

Third, the issue of asymmetric information and the principal-agent problems between individual intermediaries and regulatory agencies pose major regulatory challenges and explain why a wide array of financial institutions and other private actors should be compelled to play an active role-particularly through their dynamic and continuous relationships with public supervisors. In other words, an effective AML/CTF strategy should be based on a well-designed public-private sector partnership. ${ }^{52}$ Further, within such partnerships, the cost of AML/CTF compliance for private intermediaries and other designated subjects could be very high. One option to address these challenges is to calibrate the regulatory framework to risks.

\footnotetext{
50. See, e.g., Borlini, supra note 9 , at 3 .

51. Id. at 6 .

52. Id. at 30 .
} 


\section{The International AML/CTF Regulatory Framework}

\section{A. The Evolution of AML/CTF Law}

AML/CTF rules have undergone a gradual evolution. At the outset, they were mainly domestic rules, which imposed on banks the obligation to keep records and report transactions with a view to helping the enforcement authorities in the discharge of their duties. Things, however, started to change at the end of the eighties ${ }^{53}$ and, in particular, after the creation of the FATF in 1989. Initially, this body was designed to favor cooperation at the international level in the field of money laundering, particularly with respect to the seizure of money laundering's proceeds. Subsequently, the resurgence of international extremist Islamic terrorism brought about a proliferation of international instruments in this field, as well as the enlargement of the remit of the FATF. ${ }^{54}$ The rise of international cooperation and the mushrooming of soft- and hard-law international instruments ${ }^{55}$ in this field have been conducive to the diffusion of money laundering and terrorist financing criminal legislation. What is more, increased collaboration also resulted in the introduction of a wide array of rules aimed at involving the private sector in the prevention of these crimes. The following section will briefly look into the components of this framework.

\section{B. The FATF: A "Soft" International Organization}

In 1989, sixteen members-fifteen OECD countries and the European Commission members-established the FATF with a view to setting common international standards for AML and CTF regula-

53. See Ethan A. Nadelmann, Unlaundering Dirty Money Abroad: U.S. Foreign Policy and Financial Secrecy Jurisdictions, 18 U. Miami InTER-Am. L. Rev. 33, 34-35 (1986).

54. GILMORE, supra note 15 , at 123-24.

55. The main international treaties in the field are: United Nations Convention against Illicit Traffic in Narcotic Drugs and Psychotropic Substances, Dec. 20, 1988, 1582 U.N.T.S. 95 (entered into force Nov. 11, 1990); International Convention for the Suppression of the Financing of Terrorism, Dec. 9, 1999, 39 I.L.M. 27 (entered into force Apr. 19, 2002); Council of Europe Convention on Laundering, Search, Seizure and Confiscation of the Proceeds from Crime, Nov. 8, 1990, E.T.S. No. 141 (entered into force Sept. 1, 1993); United Nations Convention against Transnational Organized Crime, Nov. 15, 2000, 2225 U.N.T.S. 209 (with three Protocols thereto); United Nations Convention Against Corruption art. 14, Dec. 14, 2005, 2349 U.N.T.S. 41; Council of Europe Convention on Laundering, Search, Seizure and Confiscation of the Proceeds from Crime and on the Financing of Terrorism, May 16, 2005, C.E.T.S. No. 198 (entered into force May 1, 2008); Council of Europe Convention on the Prevention of Terrorism, May 16, 2005, C.E.T.S. No. 196 (entered into force June 1, 2007). 
tion. ${ }^{56}$ Currently with thirty-seven members and two observers, the FATF is the most important trans-governmental network in the field of AML. ${ }^{57}$ Trans-governmental-networks governance has a number of advantages. Given their trans-national nature, these networks are well suited to address cross-border issues. ${ }^{58}$ In addition, they generally ensure a high level of specialization of their members, not least because of the constant information sharing among them. ${ }^{59}$ Last, unlike "traditional" and more institutionalized multilateral international organizations, such as the U.N. and the World Trade Organization, they are generally more flexible and efficient. ${ }^{60}$

However, these very features also may be regarded as weaknesses in some instances. First, flexibility and informal decision-making may raise concerns about the transparency of the procedures leading to the adoption of the AML standards and third-party participation. ${ }^{61}$ Second, these networks are likely to replicate, or even magnify, the unequal distribution of power between nations. ${ }^{62}$ Third, the high degree of specialization of these networks may result in the adoption of standards that overlook a wide array of non-sectorial interests. ${ }^{63}$ Taken together, these factors undermine the legitimacy and the accountability of such networks. ${ }^{64}$ Furthermore, the peculiar characteristics of the FATF make it more difficult to determine whether it can qualify as an

56. Gilmore, supra note 15, at 91; Dennis Cox, Handbook of Anti Money Laundering 21 (2014); SimONE FAIELLA, RiciclagGIO E CRIMINE ORGANIZZATO TRANSNAZIONALE 39 (2009).

57. Eleanor D. Kinney, The Emerging Field of International Administrative Law: Its Content and Potential, 54 Admin. L. Rev. 415, 425 (2002); cf. Anne-Marie Slaughter, Governing the Global Economy through Government Networks, in The Role of LaW in International Politics: Essays in InTernational Relations and International LaW (Michael Byers ed., 2000). As mentioned above, the FATF currently comprises thirty-five member jurisdictions (including fifteen EU member states) and two international organizations (the EU is represented by the Commission). It represents major financial centres in all parts of the globe and can be rightly considered as the main global body that sets standards and supervises the fight against money laundering and terrorist financing. Alain Damais, The Financial Action Task Force, in ANTI-Money LAUndering: INTERNATIONAL LAW AND Practice 69, 73 (Wouter H. Muller et al. eds., 2007); see Gilmore, supra note 15, at 89.

58. See Anne-Marie Slaughter, A New World Order 8 (2004).

59. Kal Raustiala, The Architecture of International Cooperation: Transgovernmental Networks and the Future of International Law, 43 VA. J. INT'L L. 1, 24 (2002).

60. Id

61. Id. at 25 .

62. Id.; see also Stephen J. Toope, Emerging Patterns of Governance and International Law, in THE Role of LAW In INTERnATIONAL Politics, supra note 57, at 96-97.

63. Mitsilegas \& Vavoula, supra note 8, at 292-93.

64. See Antonio F. Perez, Who Killed Sovereignty? or: Changing Norms Concerning Sovereignty in International Law, 14 WIS. INT'L L. J. 463, 476 (1996); Sol Picciotto, Networks in International Economic Integration: Fragmented States and the Dilemmas of Neo-Liberalism, 17 Nw. J. INT'L L. \& Bus. 
international organization. Determining the nature of the FATF is not a mere theoretical exercise. In fact, should it qualify as a full-fledged international organization, it would probably be, at least to some extent, subject to the rules of international law applicable to international organizations. In this respect, it should be observed that the FATF, like many other international financial institutions, has been traditionally deemed a "soft institution." 65 This extremely fitting description, however, raises the question of whether the attribute of "softness" is inconsistent with the status of "international organization." ${ }^{66}$ According to the Draft Articles on the Responsibility of International Organizations of 2011, an international organization is "established by a treaty or other instrument governed by international law and possessing its own international legal personality. International organizations may include as members, in addition to states, other entities." 67

Although this definition seems to be modelled on a "traditional" conception of international organization, it does not rule out the possibility of qualifying the FATF as an international organization. In particular, it seems that the reference to "other instrument governed by international law" leaves the door open for a variety of institutions that do not originate from the conclusion of an international agreement. In this respect, an authoritative commentator has observed that an international agreement is not a necessary condition for the existence of an international organization. ${ }^{68}$ Nor can the status of international organization be denied because of the composition of an organization's membership. Put briefly, it is not possible to exclude the FATF as an international organization for the sole fact that non-state institutions, such as the European Commission and the Gulf Co-operation

1014, 1047 (1997); Anne-Marie Slaughter, The Accountability of Government Networks, 8 IND. J. Global Legal Stud. 347, 361-66 (2001).

65. See generally Int'L Law Ass'n, The Hague Conference (2010): International Protection OF CONSUMERS, www.rulac.org/assets/downloads/ILA_report_armed_conflict_2010.pdf (last visited Oct. 10, 2017).

66. See Jan Klabbers, Institutional Ambivalence by Design: Soft Organizations in International Law, 70 NORdIC J. INT'L L. 403, 421 (2001).

67. Int'l L. Comm'n, Draft Articles on Responsibility of International Organizations, art. 2(a), U.N. Doc. A/CN.4/L.778 (May 30, 2011). The ILC's conclusions on the point are fully consistent with the Special Rapporteur's analysis. See, e.g., Int'l Law Comm'n, Eighth Rep. on Responsibility of International Organizations, II 4, U.N. Doc. A/CN.4/640 (Mar. 14, 2011).

68. Gaetano Arangio-Ruiz, Diritto Internazionale e Personalità Giuridica 201 (1972); Condorelli, supra note 1, at 47-62; CARlo Focarelli, Trattato Di DiritTo InTERnAZionale 138-139 (2015). 
Council, are included among its members. ${ }^{69}$ What is more, the FATF bears many of the "typical" characteristics of international organizations. First, it has its own resources and a permanent structure in order to ensure an effective and continuous activity. ${ }^{70}$ Second, it monitors the implementation of its Recommendations in members' domestic legal systems. ${ }^{71}$ Third, its officials enjoy the same immunities and privileges of OECD's officials. ${ }^{72}$ In light of the above, it is possible to argue that at least some of the rules of international law applicable to international organizations (e.g., rules on immunity) could be applied to FATF.

\section{The "Hard" Impact of Global "Soft" Instruments}

The FATF Recommendations, first issued in February 1990, then revised in 1996, 2003, and 2012, ${ }^{73}$ represent the universal standards shaping AML/CTF legislation around the globe, including the EU. The Recommendations take the form of a non-binding instrument. However, as the FATF has come to serve as the international standardsetter in the AML/CTF field, its non-binding Recommendations have taken on a nearly binding character ${ }^{74}$ due to the large membership of the FATF and the sanctions mechanism that accompanies the Recommendations. ${ }^{75}$ Moreover, these quasi-binding standards often have been turned into binding provisions of international "hard" instruments and of the aforementioned U.N. Security Council Resolutions. ${ }^{76}$ Hence, in the AML/CTF field, there is a deep and dynamic interaction between soft and hard law, both depending on and strengthening the other in a recurring relationship.

The Recommendations consist of forty consolidated recommendations urging FATF Members to introduce substantive and procedural

69. Arangio-Ruiz, supra note 68; Condorelli, supra note 1, at 47-62; Focarelli, supra note 68.

70. Damais, supra note 57 , at 72 .

71. Monitoring is carried out through annual self-assessments and periodic mutual evaluations to do so. Despite FATF's limited membership, its mutual assessment methodology has also been applied in other jurisdictions. FATF-style regional bodies (FSRBs) have been established in eight regions to promote the FATF standards outside of the thirty-six FATF members. These eight FSRBs work together with the actual FATF members to create a network of nearly 200 countries. Leonardo Borlini, Soft Law, Soft Organizations e Regolamentazione "Tecnica" di Problemi di Sicurezza Pubblica e Integrità Finanziaria, 100 RIv. DIR. INT. 356, 381-85 (2017).

72. Id. at 379-80.

73. FATF Recommendations, supra note 10.

74. See Rose, supra note 3, at 191 .

75. GILMORE, supra note 15, at 133-141; Gadinis, supra note 4, at 28-32.

76. Transformation of soft law into conventional law is not a rare occurrence. For further considerations on this specific kind of "hardening" of soft law, see Treves, supra note 4, at 137-39. 
criminal rules, preventive administrative and financial measures, and measures to ensure transparency on the ownership of legal persons and arrangements. Moreover, the Recommendations enjoin the members to create ad hoc authorities with appropriate functions, powers, and mechanisms for cooperation, and strengthen their cooperation with other countries. ${ }^{77}$ In 2012, the FATF updated the content of the Recommendations by specifically addressing the following issues: (i) AML/CTF policies and coordination; (ii) money laundering and confiscation; (iii) terrorist financing and proliferation, ${ }^{78}$ (iv) preventive measures (i.e., implementing regulatory tools to prevent the use of the financial system for the purpose of money laundering, terrorist financing, and other related crimes); (v) measures to ensure transparency on the ownership of legal persons and arrangements; (vi) the establishment of competent authorities with appropriate functions; and (vii) improving powers, mechanisms, and arrangements to cooperate with other countries. ${ }^{79}$

Recommendation 1 provides that countries should identify, assess, and understand the money laundering and terrorist financing risks and ensure that measures to prevent or mitigate money laundering and terrorist financing are commensurate with the identified risks. ${ }^{80}$ Countries should also require financial institutions and designated nonfinancial businesses and professions (DNFBPs) to identify, assess, and take effective action to mitigate their money laundering or terrorist financing risks. ${ }^{81}$

Recommendation 2 is key to implementing the remaining FATF Recommendations because it defines the need to develop a national strategy based on a national risk assessment. ${ }^{82}$ In turn, this helps in setting AML/CTF public policies across different areas of government in line with the identified risks. Further, Recommendation 2 calls for countries to ensure that policy-makers, the financial intelligence units (FIUs, as discussed below), law enforcement authorities, supervisors, and other relevant competent authorities, at the policy-making and

77. See Vervaele, supra note 30 , at 387-90.

78. The second and the third elements above, thus, include both criminalization and strengthening the methods of tracing, freezing, and confiscating the proceeds of illegal activity.

79. FATF Recommendations, supra note 10 , at 16.

80. Id. at 11 .

81. Id. Recommendation 1, in conjunction with its Interpretive Note, therefore, not only sets out the expectation that all countries will apply the risk-based approach to AML/CTF, but also contains new requirements for member countries and the private sector with regard to performing and updating risk assessments.

82. Id. at 11 . 
operational levels, have effective mechanisms in place. ${ }^{83}$ These would enable them to cooperate and, where appropriate, coordinate domestically with each other concerning the development and implementation of policies and activities to combat money laundering, terrorist financing, and the financing of proliferation of weapons of mass destruction. To achieve such goals, Recommendation 2 urges the development of a national coordination plan. ${ }^{84}$ The FATF standards concern the inclusion as criminal offenses of a wide array of predicate offenses for money laundering, including "all serious offences," organized crime, and terrorism. ${ }^{85}$ Recommendation 3 clearly stipulates that countries should criminalize money laundering on the basis of the U.N. Convention against the Illicit Traffic in Narcotic Drugs and Psychotropic Substances and the U.N. Convention against Transnational Organized Crime and that they should apply the crime of money laundering to all serious offenses, with a view to including the widest range of predicate offenses. ${ }^{86}$ Recommendation 5 widens this obligation to terrorist financing and the financing of proliferation. Accordingly, countries should criminalize on the basis of the U.N. Convention on the Suppression of Terrorist Financing not only the financing of terrorist acts, but also the financing of terrorist organizations and individual terrorists even in the absence of a link to a specific terrorist act or acts. ${ }^{87}$ Countries should ensure that such offenses are designed as money laundering predicate offenses.

Several recommendations then impose preventive-administrative requirements on specific categories of private persons and institutions. These recommendations deal with customer identification and customer due diligence (CDD), record-keeping, bank secrecy, and reporting of suspicious transactions. They are not only directed to financial institutions like banks and insurance companies, but also casinos, notaries, accountants, lawyers, and companies selling and purchasing

83. Id

84. Id. The first paragraph of Recommendation 2 of the 2012 Standards provides that countries should regularly issue reviewed national AML/CTF policies informed by specific risk circumstances and "designate an authority or have a coordination or other mechanism . . . responsible for such policies." Id. The second paragraph of Recommendation 2 requires countries to have mechanisms that enable competent authorities to cooperate and coordinate concerning the development of AML/CTF strategies, at both policy and mass destruction. Id.

85. Id. at 12 .

86. $I d$.

87. Id. at 13 . 
real estate assets, art, antiquities, and precious metals. ${ }^{88}$ Their first obligation is to learn the identity of their clients and to communicate suspicious transactions. According to these requirements, any financial institution related with flows of assets should record the identity of their clients. ${ }^{89}$

In addition, Recommendations 26-28 deal with the regulation and supervision of financial institutions and DNFBPs and the powers of supervisors. ${ }^{90}$ The FATF standards also provide that every country should have financial intelligence units (FIUs), which are the public reporting institutions in charge of analyzing and investigating the suspicious transactions reports filed by the obliged entities. ${ }^{91}$ Recommendations 31 and 32 lay down the enforcement powers that FATF Members should grant to judicial investigative bodies. Finally, states must also adopt effective international cooperation measures in the criminal field, namely mutual legal-assistance requests for the taking of evidence, extradition, penalty execution, decisions of confiscation, and extinction of ownership. ${ }^{92}$

Taking all these elements into account, it is evident that the money laundering and terrorist financing counter-measures devised by the FATF constitute a new paradigm of security governance, achieved through three principal methods: criminalization, consisting of the emergence of new criminal offenses; "responsibilization," consisting of the mobilization of the private sector to cooperate with the authorities in the fight against money laundering; and private sector information, which will be administered by the FIUs. Overall, the international AML/CTF regime shaped by the FATF standards is thus characterized by a multidisciplinary approach mainly developed as two tracks: measures aimed at repressing money laundering and terrorist financing and those designed to prevent proceeds of crime from entering into the legitimate financial system. ${ }^{93}$ This model has been adopted in the

88. As money laundering/terrorist financing often requires the services of a lawyer, professional associations have often adopted voluntary codes of conduct containing obligations on money laundering. See, e.g., Am. Bar Assoc., Voluntary Good Practices Guidance for Lawyers to Detect and Combat Money Laundering and Terrorist Financing (Apr. 23, 2010).

89. FATF Recommendations, supra note 10 , at 15.

90. Id. at 23-24.

91. Id. at 24 .

92. Id. at 27-30.

93. The two groups of measures are strongly intertwined. For example, as also emphasised by Recital 7 of the Third EU AML Directive, a definition of money laundering based on a broad range of predicate offenses "facilitates the reporting of suspicious transactions and international cooperation in this area," that is to say one of the most typical obligations of the AML/CTF 
AML/CTF legislation of most countries and also the EU. In this respect, Mitsilegas and Gilmore assert that, "[s]o far, the symbiotic relationship between the development of money laundering countermeasures in international fora and the evolution of such measures in the EC/EU has been amply demonstrated." ${ }^{94}$ However, the accommodation of the criminal and preventive components of such standards within the EU has followed two different patterns, which must be addressed separately.

\section{InCORPORATING INTERNATIONAL CRIMINALIZATION STANDARDS IN EU Money LaUndering AND Terrorist FinANCING LegisLation}

\section{A. The Prohibition of AML in EU Secondary Legislation}

Similar to the U.N., the Council of Europe, and the FATF, the EU has developed AML/CTF policy that is predicated on prevention and criminalization. The EU was the first regional organization to adopt a comprehensive AML/CTF regulatory framework. However, due to EU member states' significant competence in criminal matters, criminalization turned out to be more problematic than prevention. Under EU law, there is no uniform definition of this criminal offense nor a harmonized sanctions system. ${ }^{95}$ In the context of the negotiations of the First AML Directive, the European Commission and the member states agreed to prohibit, instead of criminalize, money laundering at the EU level. ${ }^{96}$ However, this Directive also contained a declaration urging the member states to criminalize money laundering. ${ }^{97}$ The subsequent AML directives adopted the same approach. ${ }^{98}$ These instruments also stipulated definitions of money laundering and terrorist financing, similar to those in the relevant EU secondary legislation, like the EU

preventive strategy. Directive 2005/60/EC, of the European Parliament and of the Council of 26 October 2005 on the Prevention of the Use of the Financial System for the Purpose of Money Laundering and Terrorist Financing, 2005 O.J. (L 309) 15, Recital 7 [hereinafter Third AML/CTF Directive].

94. Valsamis Mitsilegas \& Bill Gilmore, The EU Legislative Framework against Money Laundering and Terrorist Finance: A Critical Analysis in the Light of Evolving Global Standards, 56 INT'L \& CoMP. L. Q. 119, 135 (2007).

95. Borlini, supra note 9 , at 16 .

96. Id. at 136.

97. Money laundering was soon criminalised in all member states. See MitsiLEGAS, supra note 15 , at 65 .

98. Directive 2001/97/EC, of the European Parliament and of the Council of 4 Dec. 2001 Amending Council Directive 91/308/EEC on Prevention of the Use of the Financial System for the Purpose of Money Laundering, 2001 O.J. (L 344) 76 [hereinafter Second AML Directive]. 
directive on the freezing and confiscation of instrumentalities and proceeds of crime adopted in $2014 .^{99}$

That being said, the lack of a pan-European definition of money laundering remains problematic as it can bring about inconsistencies in the implementation of EU secondary legislation in domestic legal systems. Notably, the persistent disagreement about the identification of predicate offenses might jeopardize the cross-border enforcement of money laundering criminal rules. ${ }^{100}$

\section{B. The Definition of Money Laundering and Terrorist Financing under EU Law}

The definitions of money laundering and terrorist financing under the law of the European Community (EC)/EU have followed two rather different patterns. The notion of terrorist financing recently appeared in the EU legal system. Article 1(5) of the Fourth AML/CTF Directive defines, in a rather detailed manner, the notion of "financing" and then refers to Council Framework Decision 2002/475/JHA to identify terroristic conducts. ${ }^{101}$

By contrast, the notion of money laundering under EC/EU law has increased its scope over time. The First AML Directive only required the member states to criminalize the laundering of drug trafficking's profit. ${ }^{102}$ By referring to Article 6 of the 1990 Council of Europe

99. Directive 2014/42/EU, of the European Parliament and of the Council of 3 April 2014 on the Freezing and Confiscation of Instrumentalities and Proceeds of Crime in the European Union, 2014 O.J. (L 127) 39.

100. European Comm'n, Indicative Roadmap for a Proposal to Harmonize the Criminal Offence of Money Laundering in the EU (Oct. 2012), http:/ / web.archive.org/web/20150928114057/ec.europa. eu/smart-regulation/impact/planned_ia/docs/2013_home_006_money_laundering_en.pdf.

101. Directive (EU) 2015/849, of the European Parliament and of the Council of 20 May 2015 on the Prevention and the Use of the Financial System for the Purposes of Money Laundering or Terrorist Financing, Amending Regulation (EU) No 648/2012 of the European Parliament and of the Council, and Repealing Directive 2005/60/EC of the European Parliament and of the Council and Commission Directive 2006/70/EC, 2015 O.J. (L 141) 83, art. 1(5) [hereinafter Fourth AML/CTF Directive]; see also Council Framework Decision 2002/475/JHA, arts. 1-4, 2002 O.J. (L 164) 3-7 (EC). "Terrorist financing" is defined as "the provision or collection of funds, by any means, directly or indirectly, with the intention that they be used or in the knowledge that they are to be used, in full or in part, in order to carry out any of the offences within the meaning of Articles 1 to 4 of Council Framework Decision 2002/475/JHA." Fourth AML/CTF Directive, supra, art. 1(5). The concept of terrorism offenses is a combination of two elements: an objective element, as it refers to a list of serious criminal conducts, as defined by reference to national law, and a subjective element, as these acts shall be deemed to be terrorist offenses when committed with a specific intent.

102. First AML Directive, supra note 11. 
Convention on Laundering, Search, Seizure and Confiscation of the Proceeds from Crime, the 1998 joint action broadened the notion of money laundering. ${ }^{103}$ In particular, it defined money laundering as "any criminal offence as a result of which proceeds were generated that may become the subject of an offence." ${ }^{104}$ The Framework Decision of June 26, 2001, ${ }^{105}$ introduced a new notion of money laundering, which encompassed all offenses punishable by deprivation of liberty or a detention order for a maximum of more than one year; or, for those states which have a minimum threshold for offenses in their legal system, offenses punishable by deprivation of liberty or a detention order for a minimum of more than six months. ${ }^{106}$

Similarly, the Fourth AML/CTF Directive lays down a rather broad definition of money laundering, ${ }^{107}$ whereby money laundering occurs regardless of whether the predicate crime was perpetrated in another EU Member State or in a third country. ${ }^{108}$ In turn, the notion of predicate crimes includes "any kind of criminal involvement in the commission of serious crimes." ${ }^{109}$ These certainly include, amongst others, drug trafficking (the only crime mentioned in the 1991 Directive), organized crime (as defined in the 1998 joint action), fraud (as defined in the EU Fraud Convention), ${ }^{110}$ corruption, and tax evasion.

Although the definition of money laundering has expanded over time, more can be done to synchronize enforcement efforts. The next section will consider the prospects for further harmonization by the EU in this field.

103. Joint Action of 3 December 1998, Adopted by the Council on the Basis of Article K.3 of the Treaty on European Union, on Money Laundering, the Identification, Tracing, Freezing, Seizing and Confiscation of the Instrumentalities and the Proceeds of Crime, 1998 O.J. (L 333) 1 [hereinafter Joint Action of 3 December 1998].

104. Council of Europe Convention on Laundering, Search, Seizure and Confiscation of the Proceeds from Crime, art. 1(e), Nov. 8, 1990, E.T.S. No. 141 (entered into force Sept. 1, 1993).

105. Council Framework Decision 2001/500/JHA of 26 June 2001, on Money Laundering, the Identification, Tracing, Freezing, Seizing and Confiscation of Instrumentalities and the Proceeds of Crime, 2001 O.J. (L 182) 1-2.

106. Borlini, supra note 9 , at 18.

107. Fourth AML/CTF Directive, supra note 101, art. 1(3) (including any manipulation of property derived from the predicate offences, whether to conceal its origin, location, disposition, movement, ownership or any other rights with respect to the property).

108. Id. art. 1(4).

109. Id. art. 3(4).

110. See Council Act of 26 July 1995, Drawing Up the Convention on the Protection of the European Communities' Financial Interests, 1995 O.J. (C 316) 49-57. 


\section{Criminalizing Laundering Crimes at the European Level?}

The Lisbon Treaty introduced Article 83 of the Treaty on the Functioning of the European Union (TFEU), which provides a specific legal basis for the adoption of EU secondary legislation aimed to fight 111 "particularly serious" crimes "having a cross-border dimension resulting from the nature or impact of such offences or from a special need to combat them on a common basis" (known as "Eurocrimes"). ${ }^{112}$ Notably, the EU can adopt directives to set common criteria concerning criminal offenses and establish the appropriate sanctions.

However, when the EU enacted stricter rules against money laundering and terrorist financing in May 2015, it invoked Article 114 TFEUthat is to say, the legal basis for harmonization of rules-instead of Article 83 TFEU. Similar to the directives of the pre-Lisbon era, these measures aimed to address the increased risk of money laundering and financial crimes stemming from deeper market integration in the EU. ${ }^{113}$ Notably, the AML/CTF directives establish a specific regime for a number of sensitive economic sectors to prevent money laundering and terrorism financing. ${ }^{114}$ Nevertheless, Article 83(1) TFEU might constitute the legal basis to enact criminal legislation to complete the existing legislative framework. As observed above, EU legislation provides for a minimum degree of harmonization of the constitutive elements and penalties for crimes, including money laundering, under Article 83(1). ${ }^{115}$ Although providing a single legal basis for the adoption of EU secondary legislation in such a vast and diverse array of fields may be problematic, ${ }^{116}$ Article 83 (1) of the TFEU may be conducive to illegalizing new forms of "Eurocrimes," 117 whose perpetration requires a common enterprise and an existing infrastructure. In such instances, harmonization is crucial in that it seeks "to create those definitions

111. See Ester Herlin-Karnell, EU Competence in Criminal Law after Lisbon, in EU LAW AFTER LisBon 343 (Andrea Biondi, Piet Eeckhout \& Stefanie Ripley eds., 2012).

112. Valsamis Mitsilegas, EU Criminal LaW 107-10 (2009).

113. Borlini, supra note 9 , at 22.

114. See Maria Bergström, EU Anti-Money Laundering Regulation: Multilevel Cooperation of Public and Private Actors, in Crime within the Area of Freedom, Security and Justice: A European Public ORDER 97 (Christina Eckes \& Theodore Konstadinides eds., 2011).

115. Council Framework Decision 2001/500/JHA, supra note 105.

116. Ester Herlin-Karnell, The Constitutional Dimension of European Criminal Law 175-77 (2012); see also Steve Peers, EU Justice and Home Affairs 780-803 (3d ed. 2011); Samuli Miettinen, Criminal LaW and Policy in the European Union 145-75 (2013).

117. Mariana Chaves, EU's Harmonization of National Criminal Law: Between Punitiveness and Moderation, 21 Eur. Pub. L. 527, 544-45 (2015). 
which act as a starting point for Member States to take criminal offences further." ${ }^{118}$ A possible EU directive harmonizing the notion of money laundering at the EU level, particularly through a more accurate definition of the relevant predicate crimes, would help forge a common understanding of this criminal offense. Consequently, this would facilitate transnational investigations, reduce firms' compliance costs for the adoption of preventive AML/CTF measures, and enhance the cooperation among member states' police, judiciaries, and FIUs. ${ }^{119}$

Notwithstanding the EU harmonizing intervention and, notably, the Third and Fourth AML/CTF Directives, EU member states' criminal laws still largely differ. In response to these persistent divergences between domestic legislations, the Commission put forward a legislative proposal amending the 2001 Framework Decision on money laundering and confiscation of proceeds of crime proposal in the context of its 2010 Action Plan implementing the Stockholm Programme. ${ }^{120}$ In 2012, the Commission drew a roadmap for a proposal of a legislative act to be adopted on the basis of Article 83(1). Its objective was twofold: harmonizing the definition of money laundering across EU member states' legal systems and replacing the 2001 framework decision. ${ }^{121}$ This legislative proposal would have completed the efforts at the EU level to tackle money laundering, and, in particular, the Third AML/CTF Directive.

After the publication of the Commission's roadmap for the proposal of a harmonization directive, the Commission's Directorate-General (DG) for Internal Market, Industry, Entrepreneurship, and Small and Medium-sized Enterprises consulted the Committee on the Prevention of Money Laundering and Terrorist Financing and issued the Report on the Application of the Third Anti-Money Laundering Directive. ${ }^{122}$ Despite the favorable opinion of several EU bodies, including EUROPOL, member states refused to endorse the project of a directive harmonizing domestic legislation on money laundering. ${ }^{123}$

118. Marco Arnone \& Leonardo S. Borlini, Corruption: Economic Analysis and InternaTIONAL LAW 240 (2014); see also HerLin-Karnell, supra note 116, at 335-35; PEers, supra note 116, at 297.

119. See supra Section III.B.

120. Action Plan on the Stockholm Program, COM (2010) 171 final (Sept. 15, 2017).

121. Joint Action of 3 December 1998, supra note 103, at 3.

122. European Commission Press Release MEMO/12/246, European Commission Report on the Application of the Third Anti-Money Laundering Directive - Frequently Asked Questions (Apr. 11, 2012).

123. See Alexandre Met-Domestici, The Reform of the Fight against Money Laundering in the EU, 3 EUCRIM 89, 90 (2013). 


\section{Forward-looking Remarks}

Formally, the 2015 AML/CTF framework does not constitute criminal law competence stricto sensu, "but rather found its expression in the notion of administrative penalties." ${ }^{124}$ Still, this framework influences both administrative and criminal national rules and procedures and deploys both criminal and administrative law enforcement tools. ${ }^{125}$ As a result, it does not leave the national criminal justice system altogether unaltered and complements national criminal law. Although the EU has not yet adopted a harmonization directive based on Article 83(1), its AML/CTF legislation has undeniably contributed to an increase of criminalization of money laundering and terrorist financing within the member states and the extension of the pertinent category of predicate offenses.

Needless to say, the terrorist attacks recently occurred on European soil gave new impetus to the adoption of legislation based on Article 83 TFEU. ${ }^{126}$ After the Paris attacks of November 2015, EU institutions and national governments decided to take further action. Thus, in December 2015, the Commission tabled a proposal for a directive on combating terrorism which comprehensively criminalizes the acts of financing of terrorist attacks and their preparation, as well as-this being the major novelty - the financing of activities such as recruitment, training, and the funding of travel abroad for terrorism purposes. ${ }^{127}$

In a similar vein, the European Commission has looked at how to improve the current AML/CTF legislation and has sped up initiatives for this purpose. As a result, in February 2016, it issued a complex action plan to strengthen the fight against terrorist financing. ${ }^{128}$ Among the different actions planned for the second half of 2016, the Commission plans to table a proposal for new EU legislation based on Article 83 (1) to harmonize the criminal sanctions for money laundering. ${ }^{129}$ This legislation rests on the following assumptions, already illustrated in the present paper: (i) terrorists often resort to criminal proceeds to

124. Ester Herlin-Karnel, The Lisbon Treaty and the Area of Criminal Law and Justice, 3 EUR. POL'Y ANALYSIS 1, 9 (2008).

125. Borlini, supra note 9 , at 24.

126. Id. at 25 .

127. Proposal for a Directive of the European Parliament and of the Council on Combating Terrorism and Replacing Council Framework Decision 2002/475/JHA on Combating Terrorism, at 18, COM (2015) 625 final (Feb. 12, 2015).

128. European Comm'n, Action Plan to Strengthen the Fight against Terrorist Financing (Feb. 2016), http:/ / ec.europa.eu/justice/criminal/files/aml-factsheet_en.pdf (factsheet).

129. Borlini, supra note 9 , at 25. 
fund their activities and use laundering schemes to convert, conceal, or acquire such proceeds; (ii) although all member states have criminalized money laundering, there are differences between member states as to the definition of the crime and the sanctions applied; and (iii) these differences create obstacles in cross-border judicial and police cooperation to tackle money laundering and are directly relevant to action against terrorist financing. ${ }^{130}$

\section{The Reform of the EU Framework on the Prevention of Money LAUNDERING AND TERRORIST FinANCING}

\section{A. The New EU AML/CTF Preventive Framework}

The EU AML/CTF framework not only seeks to harmonize national criminal legislation on money laundering, but also seeks to introduce common preventive rules. The "preventive arm" of the EU regulatory framework includes a vast array of administrative and financial measures designed to bar proceeds of crime from entering the legal financial system. The reform of EU AML/CTF legislation was prompted by the need to comply with new FATF Recommendations on the matter and the need to address the drawbacks of the AML/CTF Directive. ${ }^{131}$ Yet, the reform process has been fraught with difficulties. Due to the sensitiveness of the matter, ${ }^{132}$ the adoption of the Fourth AML/CTF Directive has been repeatedly delayed. ${ }^{133}$

The new EU legislation seeks to reconcile two different dimensions. On the one hand, it emphasizes the need to enhance international coordination to tackle an inherently transnational crime, such as

130. European Comm'n, Action Plan to Strengthen the Fight against Terrorist Financing, supra note 128 .

131. While the Directive 2015/489 enjoys pride of place in the efforts of the EU to prevent money laundering and to curb terrorist financing, it is not comprehensive in its coverage. The Directive and Regulation 2015/847 are part of a broader set of legislative measures including Commission Regulation 1889/2005, 2005 O.J. (L 309) 9 (requiring persons entering or leaving the EU to declare cash sums they are carrying if the value amounts to $€ 10,000$ or more); Council Decision 2000/642 of 17 October 2000, Concerning Arrangements for Cooperation between Financial Intelligence Units of the Member States in Respect of Exchanging Information, 2000 O.J. (L 271) 4; Directive 2007/64/EC, of the European Parliament and of the Council of 13 November 2007 on Payment Services in the Internal Market Amending Directives 97/7/EC, 2002/65/EC, 2005/60/EC and 2006/48/EC and Repealing Directive 97/5/EC, 2007 O.J. (L 319) 1 ; and a number of EU legal instruments imposing sanctions and restrictive measures on governments of third countries or non-state entities and individuals.

132. Melissa van den Broek, Preventing Money Laundering: A Legal Study on the EFFECTIVENESS OF Supervision In THE EUROPEAN UNION 16 (2015).

133. Id. 
money laundering. In particular, the AML/CTF Directive's preamble clearly states:

Money laundering and terrorist financing are frequently carried out in an international context. Measures adopted solely at national or even at Union level, without taking into account international coordination and cooperation, would have very limited effect. The measures adopted by the Union in that field should therefore be compatible with, and at least as stringent as, other actions undertaken in international fora. Union action should continue to take particular account of the FATF Recommendations and instruments of other international bodies active in the fight against money laundering and terrorist financing. ${ }^{134}$

On the other hand, the ultimate objective of this instrument remains the enhancement of market integration. This is particularly evident if one considers that the EU adopted Article 114 TFEU (approximation of laws) as a legal basis for the Fourth AML/CTF Directive and Regulation 2015/847 on the information concerning fund transfers. ${ }^{135}$ To attain these objectives, the reform sought to grant a more significant role to private actors and embrace a risk-based approach. Moreover, it introduced stricter transparency obligations with respect to the ownership of legal persons and arrangements and to improve coordination among the national FIUs.

The following analysis aims at assessing the main elements of the current EU AML/CTF preventive framework. Notably, it first takes a bird's eye view of the current regulatory framework. Then, it looks into the involvement of private actors and related problems from a fundamental freedoms and rights perspective.

\section{B. Enlarging the Scope of the Directive}

Similar to previous amendments, ${ }^{136}$ the recent reform of the EU AML/CTF framework enlarged both ratione materiae and ratione personae.

134. Fourth AML/CTF Directive, supra note 101, Recital 4.

135. The CJEU has clearly stated that measures adopted on the basis of Art. 114 TFEU must genuinely have as their object the improvement of the conditions for the establishment and functioning of the internal market. See Case C-376/98, Germany v. Parliament and Council, 2000 E.C.R. I-8419, I 83.

136. See Mitsilegas \& Gilmore, supra note 94, at 119-22. 
In terms of the former, the Fourth AML/CTF Directive lowers the cash payment threshold from $€ 15,000$ to $€ 10,000,{ }^{137}$ thereby going even beyond the threshold set out in the FATF Recommendations. ${ }^{138}$

In addition, following the approach of the newest FATF Recommendations issued in 2012, ${ }^{139}$ it expressly includes tax crimes-be they related to direct or indirect taxation ${ }^{140}$-among predicate offenses. This policy choice also seems to be functional to the EU's action against financial crimes. ${ }^{141}$ Nevertheless, it should be noted that tax crimes were already included under the previous directive insofar as they constituted serious crimes punishable by deprivation of liberty or a detention order for a maximum of more than one year. Therefore, the explicit reference to tax crimes is a symbolic choice that reveals the EU institutions' stronger political will to fight tax fraud and tax evasion. ${ }^{142}$

The reform further enlarges the scope ratione personae of AML/CTF legislation. First, it increases the number of obliged entities (i.e., entities subject to the AML/CTF obligations). For instance, it includes the providers of gambling services among obliged entities. In this respect, it seems to be consistent with the incremental pattern that has characterized AML legislation. ${ }^{143}$ While Directive 91/308/EEC included only bankers and financial institutions, the Second AML Directive added legal professionals, casinos, remittance offices, and insurance companies. ${ }^{144}$ The Third AML/CTF Directive widened the scope even more, including for the first time trusts and company service providers. $^{145}$

Secondly, the Fourth AML/CTF Directive also imposes preventive obligations on a larger number of subjects. Notably, it broadens the category of politically exposed persons (PEPs) by adopting additional

137. Fourth AML/CTF Directive, supra note 101, Recital 6. The proposal of the Commission provided for an even lower limit of 7,500 euros, but some member states considered it as an inappropriate limitation to the use of cash.

138. FATF Recommendations, supra note 10 , at 19.

139. FATF Recommendations, supra note 10, at 12.

140. Fourth AML/CTF Directive, supra note 101, art. 3(4) (f).

141. The main caveat is that the complexity of national tax laws and their differences make it extremely problematic for professionals of the financial intermediaries and other designated subjects to analyze transactions and assess the risk level of related money laundering.

142. Delphine Langlois, The Revision of the EU Framework on the Prevention of Money Laundering, 3 EUCRIM 96, 97-98 (2013).

143. See, e.g., Borlini, supra note 9 , at 29 .

144. Second AML Directive, supra note 98, at 79. On the extent to which lawyer must contribute to AML/CTF obligations, see infra Section V.E.

145. Borlini, supra note 9 , at 34 . 
provisions on PEPs at the domestic level and those working for international organizations (including the EU). ${ }^{146}$ Pursuant to Directive 2006/ 70/EC, PEPs are "natural persons who are or have been entrusted with prominent public functions," $" 47$ as well as their family members and their associates, as long as they share the beneficial ownership of legal entities or have any kind of close business relationships. ${ }^{148}$ The status of PEP ceases to apply one year after the end of an individual's time in office. ${ }^{149}$ By enlarging the number of persons subject to the PEP's regime, the directive in question seeks to minimize the risk that these persons can take advantage of their positions to commit money laundering/terrorist financing.

\section{Increasing Effectiveness: The Public-Private Partnership and the Strengthened RBA}

As observed above in Section IV.A, the Fourth AML/CTF Directive is predicated on a more effective involvement of private parties and on a risk-based approach. ${ }^{150}$ This objective is pursued by means of a wide array of instruments. These include stringent obligations on customer identification, CDD, record-keeping, and reporting of suspicious transactions. Such delegation "has opened up for changed roles for private actors in the public sector." 151 The public sector and, notably, public regulatory/supervisory bodies are entrusted only with the obligation to enforce these obligations. ${ }^{152}$

The Fourth AML/CTF Directive embraces the RBA by deploying flexible requirements with a view to lightening the burden on market participants and facilitate delivery of regulatory actions. ${ }^{153}$ The RBA

146. Fourth AML/CTF Directive, supra note 101, arts. 20-23.

147. Commission Directive 2006/70/EC of 1 August 2006, Laying Down Implementing Measures for Directive 2005/60/EC of the European Parliament and of the Council as Regards the Definition of "Politically Exposed Person" and the Technical Criteria for Simplified Customer Due Diligence Procedures and for Exemption on Grounds of a Financial Activity Conducted on an Occasional or Very Limited Basis, art. 2, 2006 O.J. (L 214) 29.

148. Id.

149. Id.

150. See supra Sections I.D, I.F.

151. Maria Bergström, Karin Svedberg Helgesson \& Ulrika Mörth, A New Role for For-Profit Actors? The Case of Anti-Money Laundering and Risk Management, 49 J. Common Mkt. STud. 1043, 1044 (2001).

152. See Heba Shams, Legal Globalization: Money Laundering Law and Other Cases 80 (2004).

153. Earlier, the focus was on enhancing the sanctioning power of regulators (ruled-based approach), whereas, since the adoption of the FATF Revised Recommendations in 2003-and, 
approach presupposes that the components (although not necessarily all of them) of the AML/CTF system-especially regulation, compliance, and control-should be framed in light of the risks that they are intended to address. The regulatory framework embraces a risk-based approach. Thus, it is based on high-level legislation setting out the main objectives to be pursued through the application of specific rules of conduct, which "need in many instances to be determined by the obliged parties themselves in light of the concrete circumstances and inherent risks." 154

The EU's AML policy proves that the RBA is generally more efficient than the rule-based approach-that is, a system of AML rules that does not take into consideration the different nature and risk profiles of enterprises. ${ }^{155}$ For one thing, it has the advantage of allowing obliged entities a relatively simple and cheap ordinary procedure for retail banking and cases without specific risk factors in general. Instead, as the level of risk increases, the obliged entities are expected to collect information about clients, particularly by means of clients' interviews. ${ }^{156}$ These interviews concern the source of the wealth, the possible destination, and the economic rationale of a given transaction. ${ }^{157}$ If a given transaction appears to be devoid of a reasonable justification, the obliged entity should ask for additional explanation. ${ }^{158}$ In case uncertainty remains or suspicion is raised, the obliged institutions have to report to the FIUs. ${ }^{159}$

Altogether, the RBA approach has a two-fold effect: it makes the regulation more flexible and intensifies the responsibilities of financial intermediaries and the other designated private subjects. These subjects, under the supervision of public regulators, design and implement a model of AML/CTF controls. In so doing, regulators set out the

even more distinctly with their last revision in 2012-it has been commonly accepted that a greater role for self-regulation of the interested sectors and individual institutions is needed. See PIETH \& Aiolfi, supra note 39, at 13-14.

154. Paolo Costanzo, The Risk-Based Approach to Anti-Money Laundering and Counter-Terrorist Financing in International and EU Standards: What It Is, What It Entails, in RESEARCH HANDBOOK ON MONEY LAUNDERING, supra note 24, at 349, 352.

155. For a critique of the rule-based approach, see Masciandaro, supra note 36. See also Report from the Commission to the European Parliament and the Council on the Application of Directive 2005/60/EC on the Prevention of the Use of the Financial System for the Purpose of Money Laundering and Terrorist Financing, COM (2012) 168 final (Apr. 11, 2012).

156. Borlini, supra note 9 , at 31 .

157. Id.

158. Id.

159. Id. 
criteria to screen financial institutions' and other obliged subjects' clients and can even reshape the internal structure of financial institutions to enhance their capacity to prevent money laundering and terrorist financing risks. ${ }^{160}$

The new EU provisions also provide for a more targeted RBA using evidenced-based risk assessments to be conducted by the Commission and member states, ${ }^{161}$ as well as guidance by the European supervisory authorities (ESAs). ${ }^{162}$ This approach also entails stricter and clearer rules on CDD in accordance with the latest FATF Recommendations. Under these new rules, banks and other obliged subjects must put in place adequate controls and procedures to gather information about their customers and their business relationship, and conduct constant monitoring thereof. ${ }^{163}$ Of particular relevance is the identification of the beneficial owner of the fund, namely the "natural person(s) who ultimately owns or controls the customer and/or ... on whose behalf a transaction or activity is conducted." 164 The expression "on behalf" is to be interpreted in an extensive manner in order to "help in the detection of more suspicious transactions." ${ }^{165}$ Not surprisingly, the identification of the beneficial owner may prove to be extremely difficult and time-consuming due to the complexity of corporate structures, which often include offshore companies. ${ }^{166}$

When carrying out these monitoring activities, the obliged entities enjoy a wide margin of discretion, and the intensity of scrutiny varies according to the level of risk. ${ }^{167}$ For instance, decisions on when and how to undertake simplified and laxer CDD will have to be justified on the basis of the low risk of transactions or customer relationships. In

160. Fourth AML/CTF Directive, supra note 101, arts. 45-46.

161. The Commission and member states shall conduct periodic risk assessments on money laundering and terrorist financing risks, respectively, affecting the EU Internal Market and relating to cross-border activities and within national jurisdictions, with a view to devising regulatory and policy options (so-called "macro" risk assessments). The underlying rationale is that in order to shape AML/CTF defences through regulation and policy, regard must be given to risk factors in the overall European or national context, as opposed to those related to specific situations which are to be performed by obliged subjects (so-called "micro" risk assessments). See Fourth AML/CTF Directive, supra note 101, arts. 6-8.

162. The Commission's risk assessments will take into account the joint opinion of the European Bank Authority, European Insurance and Occupational Authority, and the European Securities and Markets Authority. See id. art. 6(5).

163. Id. art. 13.

164. Id. art. 3(6).

165. Met-Domestici, supra note 123 , at 92.

166. See, e.g., Borlini, supra note 9 , at 32 .

167. Fourth AML/CTF Directive, supra note 101, arts. 18-24. 
this regard, it is worth noting that the ESAs must adopt guidelines on simplified CDD no later than two years after the directive enters into force. ${ }^{168}$ These new instruments adopt a more risk-based approach that should ensure a more efficient and cost-effective assessment of money laundering and terrorist financing risks. ${ }^{169}$

According to the European Council, the rules on CDD "reflect the need for the EU to adapt its legislation to take account of the development of technology and other means at the disposals of criminals." 170 For this reason, in the EU Terrorist Financing Action Plan, the Commission has sought to harden the CDD obligations of the 2015 Directive by introducing stricter and more uniform due diligence measures for high-risk third countries (i.e., third countries with deficiencies in the fight against money laundering and terrorist financing to be identified in an EU "blacklist"). ${ }^{171}$ The new plan aims at tackling new kinds of risks, such as those associated with virtual currency-exchange platforms and pre-paid instruments. ${ }^{172}$

\section{Towards Greater Effectiveness and Transparency}

The Fourth AML Directive also seeks to ensure greater effectiveness and transparency of AML disciplines. The former is pursued by enhancing cooperation between national enforcement authorities and by strengthening the sanction system of the national enforcement authorities. First, member states must favor cooperation among FIUs "regardless of their organizational status" $" 173$ and call meetings of member states' FIUs. ${ }^{174}$ Second, domestic enforcement authorities are endowed with more pervasive sanctioning powers vis-à-vis financial institutions. ${ }^{175}$ Further, the Directive establishes a "baseline sanction" for

168. Id. art. 15.

169. Borlini, supra note 9 , at 33 .

170. European Council Press Release IP/15/187, Money laundering: Council approves strengthened rules (Apr. 20, 2015).

171. Id.

172. See European Comm'n, Action Plan to Strengthen the Fight against Terrorist Financing, supra note 128 .

173. Fourth AML/CTF Directive, supra note 101, art. 52. Due to the freedom left by the third EU AML/CTF Directive in this respect, in some member states, FIUs are independent administrative bodies, whereas in others they are embedded within national police forces, or, in yet others, they are departments within a ministry. Such differences may hamper European cooperation among FIUs. For instance, when FIUs are part of the national police forces, the power to exchange information with their European counterparts may be subject to prior judicial authorization.

174. Id. art. 51.

175. Id. art. 59. 
particularly grave and repeated violations of the obligations set out therein. ${ }^{176}$ Taken together, these provisions are likely to reduce the differences between the sanction systems of the EU member states. ${ }^{177}$

On the other hand, the new and stricter transparency obligations primarily aim to prevent the establishment of complex corporate structures created for the sole purpose of circumventing AML/CTF obligations. ${ }^{178}$ To this end, similar to the FATF Recommendations, ${ }^{179}$ the Fourth AML Directive stipulates that juridical persons must disclose their beneficial owners and trustees, and keep tabs on their data. ${ }^{180}$ In turn, these subjects are required to provide the relevant information to the competent regulatory authorities and private entities discharging their CDD duties. This information will also be recorded in national registers. ${ }^{181}$ Government bodies and FIUs may access this information without any restriction, ${ }^{182}$ while obliged entities may request the information that is necessary to carry out their CDD duties. The general public, instead, must demonstrate the existence of a "legitimate interest" in having access to such information. ${ }^{183}$ In this respect, it is worth noting that the lack of an express definition of this concept in the Directive is likely to compound the interpretative divergences between member states. ${ }^{184}$

\section{E. The Balance with Protection of Fundamental Freedoms and Rights: The Emergence of a European Interest in an Effective AML/CTF Law}

As observed above, the development of EC/EU legislation on money laundering prevention and terrorist financing has been primarily inspired by FATF standards. ${ }^{185}$ Some authoritatively argue that the

176. Id.

177. Langlois, supra note 142, at 97.

178. See Fin. Action Task Force, The Misuse of Corporate Vehicles Including Trust and Company Service Providers (2006).

179. FATF Recommendations, supra note 10, at 22.

180. Fourth AML/CTF Directive, supra note 101, art. 30(1).

181. Id. arts. $30(3)-(5)$.

182. Id. arts. $30(4)(\mathrm{a}),(\mathrm{b})$.

183. Id. arts. 30(4)(c), 31(4). The final text thus struck a compromise between the initial positions of those who demanded full transparency (such as the European Parliament, which voted 640-30 in favour of public registers) and those who defended some secrecy for beneficial owners (some member states led by Germany).

184. Press Release, Transparency Int'l, EU Agrees Money Laundering Transparency Reforms, but Full Access Denied (Dec. 17, 2014), http://www.transparencyinternational.eu/wpcontent/uploads/2014/12/2014-12-17_PR-AMLD.pdf.

185. Borlini, supra note 9 , at 37 . 
" $[u]$ ncritical introduction in the Union legal order of standards challenging fundamental rights produced by an elite body with little transparency in its work ... raises important issues of legitimacy and rule of law." 186

Even without going that far, the accommodation within the EU legal order of such standards admittedly creates tensions with certain EU fundamental freedoms and rights. The issue is how to strike the right balance between the protection of such freedoms and rights and AML/CTF prevention.

In Jyske Bank Gibraltar ${ }^{187}$ and Ordre des Barreaux ${ }^{188}$ the European Court of Justice (ECJ) was asked to assess the compatibility of specific AML/CTF preventive measures with the freedom to provide services under Article 56 TFEU and the right to a fair trial enshrined in Article 6 of the European Convention on Human Rights (ECHR).

The ruling in Ordre des Barreaux has been widely commented on by the European legal community. ${ }^{189}$ For the purposes of the present Article, it suffices to recall that the ECJ ruling in Ordre des Barreaux precisely delimitated the obligation imposed on lawyers. There, the court stated that the obligation to report suspicious transactions should not apply to lawyers acting within the scope of legal counselling or judicial proceedings. ${ }^{190}$ Since the adoption of the Second AML Directive, there have been attempts to balance the conflicting interests by covering notaries and independent legal professionals primarily in the context of financial transactions. ${ }^{191}$ As a result, EU law exempts them from the Second AML Directive's obligations when they ascertain the legal positions of their clients, or they represent their clients in legal proceedings. ${ }^{192}$ It has also done so by permitting member states to

186. MitSILEGAS, supra note 112 , at 313.

187. Case C-212/11, Jyske Bank Gibraltar Ltd. v. Administración del Estado, III 58-61 (Apr. 25, 2013), http://curia.europa.eu/juris/celex.jsf?celex $=62011$ CJ0212\&lang1 $=$ en\&type $=$ TXT \&ancre $=$.

188. Case C-305/05, Ordre des Barreaux Francophones et Germanophone v. Conseil des Ministres, 2007 E.C.R. I-5305, I 16.

189. See, e.g., Michiel J.J.P. Luchtman \& Rob van der Hoeven, Case C-305/05, Ordre des Barreaux Francophones et Germanophones et al. v. Conseil des Ministres, Judgement of the Court of Justice of 26 June 2007, Grand Chamber; (2007) ECR I-5305, 46 Common Mkт. L. Rev. 301 (2009); Jan Komárek, Legal Professional Privilege and the EU's Fight against Money Laundering, 27 CIV. JusT. Q. 13 (2008).

190. Case C-305/05, Ordre des Barreaux Francophones et Germanophone v. Conseil des Ministres, 2007 E.C.R. I-5305, I 22.

191. See Fourth AML/CTF Directive, supra note 101, art. 1(3) (b).

192. Id. art. $34(2)$. 
designate an appropriate self-regulatory body other than the FIU to receive suspicious transaction reports. These bodies shall then forward the information to the FIUs promptly and unfiltered. Despite the existence of this mechanism, the reporting duties of lawyers were challenged before the Court of Justice of the European Union. ${ }^{193}$

The Court found that the challenged provisions were consistent with Article 6 of the ECHR because the Directive exhaustively list the transaction for which lawyers are required to comply with information and cooperation obligations. ${ }^{194}$ Second, referring to the exception of Article 6(3) of the Directive and solving a certain ambiguity in the text of this provision, the ECJ maintained that reporting obligations are limited to activities that take place "in a context with no link to judicial proceedings, and, consequently, those activities fall outside the scope of the right to a fair trial." ${ }^{195}$ The exemptions concerning assistance in defending the client, representation before the courts, and advice as to the manner of instituting or avoiding judicial proceedings, therefore, safeguard the right of the client to a fair trial. ${ }^{196}$

Two further considerations arise from the Ordre des Barreaux case. First, although not explicitly stated by the judges, Advocate General Poiares Maduro argued that "the objective of combating money laundering has arisen 'as an objective of general interest for the EU."”197 Second, AML/CTF obligations may come into conflict with Articles 6 and 8 of the ECHR, as it is difficult in practice to draw a line between lawyers' activities related to a trial and lawyers' activities unrelated to the conduct of judicial proceedings. ${ }^{198}$ In fact, judicial proceedings are but one area where legal privilege functions. So far, the question "has

193. The ECJ was in fact referred to by the Belgian Constitutional Court, before which the Belgian Bar Association had argued that the duty to report-as disciplined by the Belgian legislation transposing the second AML Directive including Arts. 2(a) (5) and 6, whereby the Directive is applicable to notaries and other independent legal professionals when they assist clients in commercial or financial activities-was in breach of lawyers' professional confidentiality and, hence, the right to a fair trial as protected by Art. 6 of the European Convention on Human Rights (ECHR).

194. Case C-305/05, Ordre des Barreaux Francophones et Germanophone v. Conseil des Ministres, 2007 E.C.R. I-5305, I 22.

195. Id. I] 33.

196. Id. If 34.

197. Opinion of Advocate General Poiares Maduro, Case C-305/05, Ordre des Barreaux Francophones et Germanophone v. Conseil des Ministres, 2007 E.C.R. I-05305, If 78 (emphasis added).

198. Borlini, supra note 9 , at 40 . 
not been solved in non-contentious circumstances." 199 The Ordre des Barreaux case also reveals that the definition of "ascertaining the legal position for their client"- the second situation referred to by the Directive-is open to interpretation by national courts, which also contributes to the uncertain outcome of the case of "Reporting Duty $v$. Legal Privilege." 200

The ruling in Jyske Bank Gibraltar is even more intriguing because the ECJ had to assess the compatibility of the EU AML/CTF framework with the freedom to provide services, one of the Union's four fundamental freedoms shaping its internal market. In its landmark preliminary ruling addressing the implementation of the Third AML/CTF Directive in Spain, the court, on the one hand, confirmed its usual "strict" approach in analyzing national measures which serve important interests recognized by the EU as valuable and capable of restricting one of the four fundamental freedoms. ${ }^{201}$ On the other hand, it seemed to base its judgment on a balance of interests that both appear genuinely European: the freedom to provide services, on the one hand, and the need of security and the protection of the internal market through the (national) implementation of the EU AML/CTF framework, on the other. ${ }^{202}$

To fully grasp the relevance of the ruling at issue, it is worth summarizing its factual background. Jyske Bank was a branch of the Danish Jyske Bank established in Gibraltar, which operated in Spain under the rules governing the freedom to provide services. ${ }^{203}$ Article 22(2) of the Third AML/CTF Directive-which will be replaced by the near identical Article 33(1) of the Fourth AML/CTF Directiverequires that information on suspicious transactions shall be forwarded to the FIUs "of the Member State in whose territory the institution or person forwarding the information is situated." ${ }^{204}$ Pursuant to Spanish law, credit institutions operating in Spain must inform the Spanish FIU of transfers of more than $€ 30,000$ to or from tax havens and uncooperative territories, such as Gibraltar. ${ }^{205}$ Jyske bank complied with the

199. Maaike Stouten \& André Tilleman, Reporting Duty for Lawyers Versus Legal Privilege:

Unresolved Tension, in Research Handbook on Money LaUndering, supra note 24, at 426, 431.

200. Id.

201. Case C-212/11, Jyske Bank Gibraltar Ltd. v. Administración del Estado, supra note 187,

II $60-66$.

202. Id. II $43-57$.

203. Id. II 22 .

204. Third AML/CTF Directive, supra note 93, at 27 (emphasis added).

205. Case C-212/11, Jyske Bank Gibraltar Ltd. v. Administración del Estado, supra note 187, If

20. Territories regarded as tax havens and uncooperative territories were specified by Royal 
request forwarded by the Spanish FIU only partially, invoking the banking secrecy in force in Gibraltar, resulting in a fine of $€ 1,700,000$. The bank appealed the decision before the Spanish Supreme Court, which referred the case to the ECJ. ${ }^{206}$ The analysis of the Luxembourgbased court was twofold. It first examined Article 22 of the Third AML/CTF Directive and then Article 56 TFEU, although the domestic court did not refer to the latter provision in its question. ${ }^{207}$

According to the judges, Article 22 of the Third AML/CTF Directive is rather clear and should be read:

as meaning that the entities referred to must forward the requested information to the FIU of the Member State in whose territory they are situated, that is to say, in the case of operations performed under the rules on the freedom to provide services, to the FIU of the Member State of origin. ${ }^{208}$

Yet, the ECJ stretched the limits of the provision by asserting that it "does not expressly prohibit" the host Member State from requiring a credit institution carrying out activities in its territory under the rules on the freedom to provide services to forward the information referred directly to its own FIU "in so far as such legislation seeks to strengthen... the effectiveness of the fight against money laundering and terrorist financing." 209 According to the ECJ, however, credit institutions remain obliged to supply the required information to the FIU of the home state, which are in turn asked to cooperate with FIUs of other EU countries. $^{210}$

Regarding Article 56 TFEU, the ECJ affirmed that a national measure such as the one adopted by Spain constitutes a restriction on the freedom to provide services when it implies costs and is additional to the controls already conducted in the Member State where the institution in question is situated. ${ }^{211}$ After concluding that there was indeed a restriction on the aforementioned freedom, the court assessed whether

Decree 1080/1991 of 5 July 1991 (B.O.E. 1991, 167) (Spain) and by Order ECO/2652/2002 of 24 October 2002, Implementing Reporting Obligations in respect of Transactions Conducted with Certain Countries, which Must Be Notified to the Executive Service of the Commission for the Prevention of Money Laundering and Monetary Offences (B.O.E. 2002, 260). Gibraltar is on this list. 206. Case C-212/11, Jyske Bank Gibraltar Ltd. v. Administración del Estado, supra note 187, II 2. 207. Id. If 38 .

208. Id. I 43

209. Id. II 45, 49 (emphasis added).

210. Id. II 51,54 .

211. Id. I 60 . 
national legislation was justified by an "overriding requirement relating to the public interest" and whether the same legislation was appropriate and proportional for securing the attainment of the aim it pursued. $^{212}$

As for the first question, the ECJ affirmed that the prevention and the combating of money laundering and terrorist financing are "legitimate aims" ${ }^{213}$ : AML was already recognized as a public interest in a previous judgment concerning gambling services in France. ${ }^{214}$ The ECJ then determined that the national legislation was appropriate to attain the objective it pursues because domestic legislation like the Spanish one enables the member state concerned to require at any time, "where there is reasonable doubt as to the legality of a financial transaction," information necessary to pursue and punish alleged perpetrators of the crime and because it is non-discriminatory, as all operators are subject to similar obligations. ${ }^{215}$

The application of the proportionality test is more intriguing. According to the court's reasoning, the mechanism of cooperation between FIUs presents some flaws that impede authorities from acting quickly. ${ }^{216}$ National legislation thus meets the standard of proportionality to the extent that it requires:

[C]redit institutions situated in another Member State to forward, concerning operations carried out under the freedom to provide services, information necessary for combating money laundering and terrorist financing directly to the FIU of the host Member State, only where there is no effective mechanism ensuring full and complete cooperation between the FIUs and allowing money laundering and terrorist financing to be combated just as effectively. ${ }^{217}$

The judges maintained that, at least for the time being, FIUs are not obliged to automatically forward information to the FIUs of another

212. Id.

213. Id. If 62.

214. Case C-212/08, Zeturf Ltd. v. Premier Ministre, 2011 E.C.R. I-5633, II I 45-46.

215. Case C-212/11, Jyske Bank Gibraltar Ltd. v. Administración del Estado, supra note 187 , I 65.

216. Id. II $73-75$.

217. Id. I[ 81 (emphasis added). 
Member State. ${ }^{218}$ Moreover, inasmuch as Spanish legislation was limited to operations exceeding $€ 30,000$ and involving transfers of funds from or toward certain territories, it did not appear to be disproportionate. ${ }^{219}$ Interestingly, the court did not investigate the existence of less restrictive alternatives. Rather, it focused on the EU AML/CTF and considered AML/CTF as a "European" interest. ${ }^{220}$ In so doing, the ECJ assumes a genuine European perspective.

\section{F. The Uneasy Relationship between AML/CTF Law, the Right to Privacy, and Data Protection Law}

The problematic coexistence of the right to a fair trial and the freedom to provide service does not exhaust the list of possible interferences with fundamental rights of the preventive system designed by EU AML/CTF legislation to accommodate the international soft law in the field. This system indeed requires the processing and exchange of personal data (e.g., in customer identification, due diligence, and reporting duties) in order to be able to detect criminals who might hide behind the customers of an entity subject to the vigilance obligations of the Directive. To assess the problematic interaction of the last AML Directive with the rights in question, we should first sketch out the legal regime of such rights in the EU.

\section{The Protection of the Right to Privacy and the Protection of}

Personal Data under International Law and EU Law

The right to privacy can be defined as the right to be protected from unjustified interferences of states and private agents in individuals' private lives. ${ }^{221}$ Such illegal interferences may take various forms. Of particular relevance for the purposes of the present study are the violations of the right to privacy linked to the processing of personal data. ${ }^{222}$ As early as 1988, the U.N. Human Rights Committee recog-

218. This will not change under the reinforced cooperation established by the fourth AML/CTF Directive.

219. Case C-212/11, Jyske Bank Gibraltar Ltd. v. Administración del Estado, supra note 187 , I 83.

220. Id. II 85 .

221. See Susan Marks \& Andrew Clapham, Human Rights Lexicon 262 (2005).

222. It has been aptly noted that the right to privacy does not necessarily overlap with the protection of personal data. See Carlo Focarelli, LA PRIVACy: ProtegGere I DATI PERSONALi OGGI $36-37$ (2015); Juliane Kokott \& Christoph Sobotta, The Distinction between Privacy and Data Protection in the Jurisprudence of the CJEU and the ECtHR, 3 INT'L DATA PRIVACY L. 222 (2013). 
nized that such a right has important implications with respect to the processing and storage of personal data on computers and databases. ${ }^{223}$ In particular, it observed that:

The gathering and holding of personal information on computers, data banks and other devices, whether by public authorities or private individuals or bodies, must be regulated by law. Effective measures have to be taken by States to ensure that information concerning a person's private life does not reach the hands of persons who are not authorized by law to receive, process and use it.... In order to have the most effective protection of his private life, every individual should have the right to ascertain in an intelligible form, whether, and if so, what personal data is stored in automatic data files, and for what purposes. Every individual should also be able to ascertain which public authorities or bodies control or may control their files. $^{224}$

With the advent of the digital era, the debate on the human rights implications of the processing of personal data became even more crucial. Upon mandate of the U.N. General Assembly, the Office of the High Commissioner for Human Rights drafted a report on the right to privacy in the digital era. ${ }^{225}$ Notably, this report emphasizes the need to address the possible human rights issues raised by the increasingly important role of databases. ${ }^{226}$

The right to privacy is also protected under regional human rights instruments. In the context of the Council of Europe, the two most notable instruments are the Convention for the Protection of the Individuals with regard to Automatic Processing of Personal Data and the European Convention on Human Rights. In the EU legal system, the right to privacy and the protection of personal data are included among the general principles of EU law and are enshrined in Articles 7 and 8 of the Charter of Fundamental Rights of the European Union as

223. U.N. Human Rights Comm., General Comment No. 16: Article 17 (The Right to Respect of Privacy, Family, Home and Correspondence, and Protection of Honour and Reputation), II 10, U.N. Doc. HRI/GEN/1/Rev.9 (Vol. I) (Apr. 8, 1988).

224. Id.

225. U.N. Office of the High Commissioner for Human Rights, The Right to Privacy in the Digital Age, U.N. Doc. A/HRC/27/37 (June 30, 2014).

226. Id. ๆ 14. 
well as in Article 16 TFEU. ${ }^{227}$ In addition, the protection of personal data and the right of privacy find express recognition in a number of EU secondary law instruments. ${ }^{228}$ More widely, the EU has attempted to square the storage and processing of personal data for security purposes with the protection of fundamental rights. This attitude was particularly evident during the negotiation of the so-called SWIFT Agreement, ${ }^{229}$ where EU institutions and, notably, the European Parliament, have striven for limiting the negative impact on fundamental rights of rules governing the exchange of personal financial data.

\section{The Remaining Tensions between AML/CTF Law, the Right to Privacy, and Data Protection Law}

The European legislature has gradually attempted to reconcile AML legislation with the right to privacy. The existence of an EU interest to modulate data protection prerogatives for the purposes of AML/CTF prevention is acknowledged in the very text of the Directive, which states that "the processing of data" for those purposes "shall be considered as a matter of public interest under Directive 95/56EC." "230

The new instrument addresses some of the concerns that the European Data Protection Supervisor (EDPS) expressed in its opinion of July 2013 on the Commission's proposal for the Fourth AML Directive. ${ }^{231}$ Most notably, the Directive now contains substantive provisions

227. See generally Gloria González Fuster, The Emergence of Personal Data Protection as a Fundamental Right of the EU (2014).

228. See, e.g., Regulation (EU) 2016/679, of the European Parliament and of the Council of 27 April 2016 on the Protection of Natural Persons with regard to the Processing of Personal Data and on the Free Movement of Such Data, and Repealing Directive 95/46/EC (General Data Protection Regulation), 2016 O.J. (L119) 1; Directive (EU) 2016/680, of the European Parliament and of the Council of 27 April 2016 on the Protection of Natural Persons with regard to the Processing of Personal Data by Competent Authorities for the Purposes of the Prevention, Investigation, Detection or Prosecution of Criminal Offences or the Execution of Criminal Penalties, and on the Free Movement of Such Data, and Repealing Council Framework Decision 2008/977/JHA, 2016 O.J. (L 119) 89.

229. Agreement between the European Union and the United States of America on the Processing and Transfer of Financial Messaging Data from the European Union to the United States for Purposes of the Terrorist Finance Tracking Programme, 2010 O.J. (L 8) 11.

230. Fourth AML/CTF Directive, supra note 101, art. 43 (emphasis added); Directive 95/46/EC of the European Parliament and of the Council of 24 October 1995 on the Protection of Individuals with regard to the Processing of Personal Data and on the Free Movement of Such Data, 1995 O.J. (L 281) 31, art. 13.

231. Eur. Data Prot. Supervisor, Opinion of the European Data Protection Supervisor on a Proposal for a Directive of the European Parliament and of the Council on the Prevention of the Use of the Financial System for the Purpose of Money Laundering and Terrorist Financing, and a Proposal for a Regulation of the 
that explicitly refer to the applicable EU data protection law as transposed into national law and recall the principle of providing data subjects with information about the processing of data for AML/CTF purposes. ${ }^{232}$ It establishes a maximum temporal limit for the retention of data collected to comply with the record-keeping obligations after the end of the business relation with the customers (the data subjects) or after the date of an occasional transaction. ${ }^{233}$ Finally, Article 39 stipulates that the obliged entities and their managers and employees shall not divulge the information reported to the FIUs in accordance with Article 33 and 34 of the same Directive. ${ }^{234}$ When enacting this prohibition, the member states may restrict the data's subject right of access to personal data on condition that such a restriction (i) "constitutes a necessary and proportionate measure in a democratic society"; (ii) does not hinder the obliged entities and national authorities in the discharge of their reporting duties; (iii) and does not hamper the prevention and the repression of money laundering and terrorist financing. ${ }^{235}$

Nevertheless, other solutions' provisions are far more controversial. First, member states are required to give FIUs maximum access to national databases ("financial, administrative, and law enforcement information") ${ }^{236}$ however, as with the Third Directive, no data protection provisions accompany this maximum access. Also, notwithstanding the clear indication from the EDPS, the Directive does not expressly clarify whether (and which) sensitive data within the meaning of Article $8(1)$ of Directive $95 / 46$ have to be taken into account in carrying out CDD.

Secondly, the weak safeguards for the right to access data are even more worrying: as observed early, under the Directive it is left to member states to adopt legislative measures restricting the right of access of the data subject due to the prohibition of tipping-off to the extent that such limitation "constitutes a necessary and proportionate measure in a democratic society." ${ }^{237}$ Yet, the lack of further details can

European Parliament and of the Council on Information on the Payer Accompanying Transfers of Funds (July 4, 2013), https://edps.europa.eu/sites/edp/files/publication/13-07-04_money_laundering_en. $\underline{\text { pdf. }}$

232. Fourth AML/CTF Directive, supra note 101, arts. 41(1)-(3).

233. Id. art. $40(1)$

234. Id. art. $39(1)$

235. Id. art. $41(4)$.

236. Id. art. 32(4).

237. Id. art. 41(4). 
result in undue discrepancies among member states, and it seems disproportionate to limit the access right in relation to those suspicious transactions reports that are later considered groundless and irrelevant. a matter on which the Directive is silent. ${ }^{238}$ This is a serious omission; the right to access is indeed protected by Article 8 of the Charter of Fundamental Rights of the EU (the Charter), ${ }^{239}$ and any limitation must be strictly interpreted. The EU legislator, therefore, at least should have issued some guidelines as to when such limitation could be considered necessary and proportionate and mentioned that this limitation should be used on an exceptional basis. ${ }^{240}$

Thirdly, the length of the retention period of the data is extremely problematic. Recital 44 and Article 40 of the Directive provide that obligated entities shall maintain the information obtained through due diligence measures as well as records of the transactions for at least five years after the end of the business relationship with their customer or after the date of an occasional transaction. ${ }^{241}$ Further, such a retention period may be extended by member states for an additional five years after a thorough assessment of the necessity and proportionality of further retention when this is considered to be necessary for the prevention, detection, or investigation of money laundering or terrorist financing. ${ }^{242}$ In this respect, it has been observed that, in giving member states a large amount of leeway, the rules on the possible extension of the retention period raise serious proportionality concerns. $^{243}$ Therefore, it would have been better if, as the EDPS had suggested, the Fourth AML/CTF Directive provided for a possible extension of the retention period after a thorough assessment on a case-by-case basis or, at least, for specific guidelines as to the circumstances under which such an extension would be necessary. ${ }^{244}$

Our take is that the choice of including only apodictic statements on the duration of the data retention period is all the more striking in view of the outcome of the recent jurisprudence of the Court of Justice of the European Union (CJEU) on the right to privacy and the right to data protection. Particularly, it seems that the EU legislator ignored the

238. See Eur. Data Prot. Supervisor, supra note 231, I 65.

239. Charter of Fundamental Rights of the European Union, 2012 O.J. (C 326) 391.

240. Mitsilegas \& Vavoula, supra note 8, at 281.

241. Borlini, supra note 9 , at 43 .

242. Id.

243. Mitsilegas \& Vavoula, supra note 8, at 281; see Eur. Data Prot. Supervisor, supra note 231, at 14 .

244. See Eur. Data Prot. Supervisor, supra note 231, at 14 
potent echo of the milestone ruling in Digital Rights. ${ }^{245}$ Although the ruling was rendered in a different context, ${ }^{246}$ the main motivations that led the court to hold that the EU legislature had exceeded the limits of the principle of proportionality in relation to certain provisions of the Charter (Articles 7, 8, and 52(1) ) by adopting the Directive 2006/24 ${ }^{247}$ and, hence, struck down the same Directive-seem staggeringly pertinent for the analysis of the Fourth AML/CTF Directive. Similarly to the latter act, the "material objective" of the data retention Directive is crime prevention, especially prevention of serious crimes like terrorism. ${ }^{248}$ In invalidating Directive 2006/24 because of its excessive interference with fundamental rights, the focus of the court's reasoning was on its problematic rules on the definition of "serious crime" and the duration of the data retention period. ${ }^{249}$ The Directive lacked a definition of "serious crime," and, hence, left the provisions excessively generic. ${ }^{250}$ Furthermore, in the court's reasoning, it was not possible to reconcile the excessive length of the retention period (i.e., a maximum of two years) with the stated aims of the Data Retention Directive. The reason being that the issue of proportionality - which plays a particularly relevant role with respect to Articles 7 and 52 of the Charter-was not sufficiently addressed in this instrument. ${ }^{251}$ Therefore, the CJEU stated that the EU legislature had "exceeded the limits imposed by compliance with the principle of proportionality" for a practice-mass surveillance established by Directive 2006/24-that interfered with

245. Joined Cases C-293/12 \& C-594/12, Digital Rights Ireland Ltd. v. Minister for Commc'ns, Marine and Nat. Res., (Apr. 8, 2014), http://curia.europa.eu/juris/document/document. jsf?docid $=150642 \&$ doclang $=\mathrm{EN}$.

246. Space precludes a full account of the case. See, e.g., Oreste Pollicino \& Marco Bassinio, The Luxembourg Sense of the Internet: Towards a Right to Digital Privacy?, in The Global Community: YEARBoOK of INTERNATIONAL LAW AND JuRISPRUdENCE 2014 223, 223-46 (Giuliana Ziccardi Capaldo ed., 2015); Arianna Vedaschi \& Valerio Lubello, Data Retention and Its Implications for the Fundamental Right to Privacy: A European Perspective, 20 Tilburg L. Rev. 14 (2015).

247. Directive 2006/24/EC, of the European Parliament and of the Council of 15 March 2006 on the Retention of Data Generated or Processed in Connection with the Provision of Publicly Available Electronic Communications Services or of Public Communications Networks and Amending Directive 2002/58/EC, 2006 O.J. (L 105) 54.

248. The court indeed assessed the proportionality of the Directive in light of its "material objective" - crime prevention-rather than its stated objective-market harmonization. See Joined Cases C-293/12 \& C-594/12, supra note 245, III 56-59. It is no secret that the legislative process that led to the adoption of the Directive found strong impetus in the aftermath of the terrorist attacks in Madrid in March 2004 and in London in July 2005.

249. Id. II $46-56$.

250. Id. I 57.

251. Borlini, supra note 9 , at 44 . 
fundamental rights, especially the right to privacy and the right to data protection. ${ }^{252}$ Such a conclusion mirrors Advocate General (AG) Cruz Villalón's reflections in his opinion in Digital Rights. Indeed, the AG noted that:

[A] human being lives out his existence over a period which is by definition limited where the past, his own history and in the final analysis his memory, and the present, the more or less immediate lived experience, the awareness of what he is in the process of living through, converge .... What appears unquestionable is the possibility of distinguishing between the perception of present time and the perception of the past. In each of those perceptions, an individual's awareness of his own life, his 'private life' particularly, as a 'recorded' life may play a part. Further, there is a difference according to whether that 'recorded life' is the one which is perceived as his present or the one which is experienced as his own history. ${ }^{253}$

AG Cruz Villalón went on to argue that such considerations could be applied to the analysis of the proportionality of the data retention obligation as defined by the Data Retention Directive. In particular, he observed that:

if the principle of retaining all that personal documentation for a certain period of time is considered lawful, it remains to ask whether it is inevitable, that is to say, necessary, for it to be imposed on individuals over a period which covers not only "the present time" but also "historical time." 254

252. Id.

253. Opinion of Advocate General Cruz Villalón (Dec. 12, 2013), Joined Cases C-293/12 \& C-594/12, Digital Rights Ireland Ltd. v. Minister for Commc'ns, Marine and Nat. Res., If 146. See also Norbert Elias, Du temps (1998); Hartmut Rosa, Accélération: Une critique sociale du TEMPS (2013).

254. Opinion of Advocate General Cruz Villalón, supra note 253, II 147. Also, "it may be considered that a retention period for personal data 'which is measured in months' is to be clearly distinguished from a period 'which is measured in years.' The first period would correspond to that falling within what is perceived as present life and the second to that falling within life perceived as memory. The interference with the right to privacy is, from that perspective, different in each case and the necessity of both types of interference must be capable of being justified." Id. If 148 . 
He then concluded that "[a]lthough the necessity of the interference in the dimension of present time seems to be sufficiently justified," he found "no justification for an interference extending to historical time," 255 and that, in the various views defending the Data Retention Directive, he did not find "any sufficient justification for not limiting the data retention period to be established by the member states to less than one year." ${ }^{256}$

The ruling in Digital Rights was reinforced by another important judgment recently issued by the ECJ. In Tele $2,{ }^{257}$ the court was once again seized to assess the consistency of the data retention obligations with EU law. First, it assessed whether a domestic measure imposing on electronic communication service providers the obligation to retain personal data is consistent with Article 15(1) of the Directive 2002/58/ EC, ${ }^{258}$ as amended by Directive 2009/136/EC ${ }^{259}$ of the European Parliament and of the Council of 25 November 2009, read in conjunction with Articles 7, 8, and 11 and Article 52(1) of the Charter of Fundamental Rights of the EU. This provision provides that:

Member States may adopt legislative measures to restrict the scope of the rights and obligations provided for in Article 5, Article 6, Article 8(1), (2), (3) and (4), and Article 9 of this Directive when such restriction constitutes a necessary, appropriate and proportionate measure within a democratic society to safeguard national security (i.e. State security), defence, public security, and the prevention, investigation, detection

255. Id. I 149.

256. Id. (emphasis added). The AG went on, stating that: "In other words, and with all the caution that this aspect of the review of proportionality always requires, no argument was able to convince me of the need to extend data retention beyond one year." Id.

257. Joined Cases C-203/15 \& C-698/15, Tele2 Sverige AB v. Post-och telestyrelsen, Sec'y of State for the Home Dep't v. Watson (Dec. 21, 2016)) 016 E.C.R.his date, but incper under 21.5.2. Online sources seem to indicate eh ughout hte ent. I'I was thinking the document s, http://curia. europa.eu/juris/document/document.jsf?docid $=186492 \&$ doclang $=\mathrm{EN}$.

258. Directive 2002/58/EC, of the European Parliament and of the Council of 12 July 2002 concerning the Processing of Personal Data and the Protection of Privacy in the Electronic Communications Sector (Directive on Privacy and Electronic Communications), 2002 O.J. (L 201) 37.

259. Directive 2009/136/EC, of the European Parliament and of the Council of 25 November 2009 Amending Directive 2002/22/EC on Universal Service and Users' Rights Relating to Electronic Communications Networks and Services, Directive 2002/58/EC concerning the Processing of Personal Data and the Protection Of Privacy in the Electronic Communications Sector and Regulation (EC) No 2006/2004 on Cooperation between National Authorities Responsible for the Enforcement of Consumer Protection Laws, 2009 O.J. (L 337) 11. 
and prosecution of criminal offences or of unauthorised use of the electronic communication system, as referred to in Article 13(1) of Directive [95/46]. To this end, Member States may, inter alia, adopt legislative measures providing for the retention of data for a limited period justified on the grounds laid down in this paragraph. All the measures referred to in this paragraph shall be in accordance with the general principles of Community law, including those referred to in Article 6(1) and (2) of the Treaty on European Union. ${ }^{260}$

In the court's view, this disposition should be construed as an exception to the general prohibition to store personal data. ${ }^{261}$ In addition, the court emphasized that the measures referred to in Article 15 (1) should be consistent with the general principles of EU law. ${ }^{262}$ It follows that such a provision shall be read in light of the right to privacy and protection of personal data under Articles 7 and 8 of the Charter of Fundamental Rights of the European Union. ${ }^{263}$ Bearing this in mind, the court concluded that the sweeping obligation to retain personal data enacted by Sweden ran afoul of Article 15(1) of the Directive 2002/58/EC, as amended by Directive 2009/136/EC. ${ }^{264}$

The second preliminary question concerned the consistency with the abovementioned Article 15 of a measure conferring on national authorities the power to have unrestricted access to personal data. ${ }^{265}$ In this respect, the court first observed that national authorities should be allowed to access such data only in accordance with the principle of proportionality. ${ }^{266}$ It follows that the access to such data should be subject to substantive and procedural provisions. ${ }^{267}$ Notably, the court held that:

[I]t is essential that access of the competent national authorities to retained data should, as a general rule, except in cases of validly established urgency, be subject to a prior review carried out either by a court or by an independent administrative body,

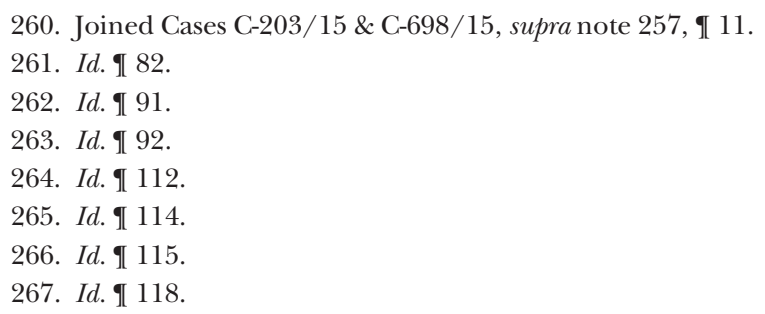


and that the decision of that court or body should be made following a reasoned request by those authorities submitted, inter alia, within the framework of procedures for the prevention, detection or prosecution of crime. ${ }^{268}$

In light of the foregoing considerations, the court had little difficulty in concluding that Article 15 precluded member states from conferring such far-reaching powers on their national authorities. ${ }^{269}$

Arguably, these decisions should be considered as strong warnings regarding any future EU legislation in the field, especially considering that the EDPS also expressed concerns on the length of the data retention period. However, it should be noted that the Fourth AML/ CTF Directive did not fully take into account the findings of the court. In fact, the definition of money laundering contained in the Fourth AML/CTF Directive rests upon an open-ended definition of "serious" predicate "crimes," which might turn out to be inconsistent with the principle of legal certainty. ${ }^{270}$ What is more, the extensible five-year data retention period contained in the same Directive might be at variance with the proportionality principle. ${ }^{271}$

Finally, the European Commission's ${ }^{272}$ call for an enhanced exchange of financial intelligence among EU FIUs and third country FIUs and among FIUs and the private sector may compound the privacy and data protection concerns raised by the Fourth AML/CTF Directive. ${ }^{273}$ In this context, the Commission remarks that international standards now emphasize the importance of extending the scope of the access to the information available to FIUs, and this will be achieved by means of an amendment of the Fourth AML/CTF Directive. ${ }^{274}$ Yet, in another landmark ruling on the right to data protection, the Court of Justice had already held that the transfer of everyday personal data to third countries on large scale without substantive assessment of the adequacy of their data protection framework is incompatible with the EU Charter of Fundamental Rights. ${ }^{275}$ In this

268. Id. ๆ 120.

269. Id. I 125 .

270. Borlini, supra note 9 , at 45.

271. See Eur. Data Prot. Supervisor, supra note 231, at 14.

272. See European Comm'n, Action Plan to Strengthen the Fight against Terrorist Financing, supra note 128 .

273. Mitsilegas \& Vavoula, supra note 8, at 291.

274. Id. at 291-92.

275. Case C-362/14, Schrems v. Data Prot. Comm'r (Oct. 6, 2015), http://eur-lex.europa.eu/ legal-content/EN/TXT/PDF/?uri=CELEX:62014CJ0362\&from=EN. 
respect, it is welcome that the European Commission seems to have put matters right in its last Proposal for a directive amending the Fourth AML/CTF Directive, which does not contain the above referred modification. ${ }^{276}$

\section{Conclusion}

The last twenty-five years have seen an upsurge of legislative and regulatory instruments aimed at contrasting newly perceived global threats-those of money laundering and terrorist financing. An exceptional normative production of international standards took place, "largely the outcome of a broad political consensus and synergies between the global, regional and national level," 277 as well as of the economic analysis of laundering crimes and AML/CTF regulation. In this context, the FATF "soft law" standards had a tremendous impact on domestic and international AML/CTF rules. It is not by chance that the FATF has been defined as "the single most influential international body in terms of formulation of anti-money-laundering policy and mobilization of global awareness of the complex issues involved in countering this sophisticated form of criminality." ${ }^{278}$

Our investigation of the "genealogy" of the international AML/CTF norms, their criminological and economic rationales and the resulting normative prescriptions suggests that it is unsurprising that a highly detailed legal framework, such as the current AML/CTF law, has found its first and natural "body" in a soft law instrument adopted by a technocratic body and only thereafter has been translated into binding international legal instruments. Flexibility and openness to change typical of soft law are particularly important in a field where domestic laws and regulations, as well as enforcement actions, have to keep pace with money launderers and terrorist financiers to remain effective. Further, soft law instruments are generally considered more suitable to regulate technical matters because nations are generally wary of undertaking excessively stringent commitments immediately.

FATF standards and hard law have influenced one another. On the one hand, FATF standards have shaped the content of hard law in the AML/CTF field. On the other hand, domestic and regional legal

276. Proposal for a Directive of the European Parliament and of the Council Amending Directive (EU) 2015/849 on the Prevention of the Use of the Financial System for the Purposes of Money Laundering or Terrorist Financing and Amending Directive 2009/101/EC, COM (2016) 450 final (July 5, 2016).

277. Mitsilegas, supra note 112, at 312.

278. Gilmore, supra note 15 , at 89. 
regimes incorporating FATF standards have strengthened the legitimacy and relevance of the FATF.

The EU was the first regional polity to play an active role in shaping global standards and has constantly sought to keep pace with AML/ CTF global soft law. Yet, the implementation of such standards has often been fraught with difficulties. ${ }^{279}$

First, the accommodation of the criminal and preventive components of international AML/CTF standards within the EU has followed two rather diverging paths. Indeed, the adoption of an EU criminal legislation on money laundering has been impeded so far by the member states' reluctance to concede the EU more powers in the criminal law field, particularly in harmonizing the definition and sanctions of certain crimes. As a result, whilst harmonization of criminal systems, foreseen in Article 83 TFEU, is still a process in development, ${ }^{280}$ and the persisting differences in the member states' legislations on the definition of money laundering and sanctions have led to difficulties for judicial and police cooperation and cross-border investigations. The EU has so far adopted four directives (and a series of other measures) on prevention that have been justified by the need to accommodate the FATF Recommendations in EU law.

With its new provisions designed to increase the effectiveness and efficiency of the AML/CTF preventive framework, the 2015 Directive fully incorporated the FATF Recommendations on prevention. Besides representing one of the key actions of the European Security Agenda, ${ }^{281}$ the Directive is a salient example of large-scale public-private security cooperation and an important but rather discrete case of data-led fight against terrorism.

Second, the incorporation of FATF soft law standards into EU legislation often does not sit comfortably with fundamental freedoms and rights protected under EU law. Such tensions are further exacerbated by the circumstance that, within the EU, the prevention of money laundering and (even more so) terrorist financing is increasingly viewed as a security issue. In Jyske Bank and Ordre des Barreaux, the Court of Justice of the European Union found that the fight against

279. See Mitsilegas \& Gilmore, supra note 94, at 140.

280. As documented, a new thrust for the adoption of EU criminal instruments in the AML/CTF field has followed the publication of the Commission Action Plan for Strengthening the Fight against Terrorist Financing last February. See PeErs, supra note 116, at 813-30.

281. See Communication from the Commission to the European Parliament, the Council, the European Economic and Social Committee and the Committee of the Regions: The European Agenda on Security, COM (2015) 185 final (Apr. 28, 2015). 
money laundering and terrorist financing is an objective of general interest. Therefore, it concluded that AML/CTF measures may introduce proportionate and reasonable restrictions to the freedom to provide services and the right to a fair trial. Striking a similar balance between the AML/CTF legislation and the fundamental rights to privacy and data protection seems far more problematic. Whereas the data protection rules as formulated in the final text of the 2015 Directive represent a significant step forward compared to the previous regime, states still enjoy a significant degree of discretion.

The above-described landscape displays the limits of adopting the normative outcome of an organization like the FATF within the wider EU legal framework with a view to responding to security threats. The tension between the EU legislation incorporating the global AML/CTF soft law and the right to privacy is likely to remain unsolved. The recent proposal of an amendment to the Fourth AML/CTF Directive (socalled "Fifth AML/CTF Directive") ${ }^{282}$ seems to confirm such proposition. It suffices to note that in its recent opinion on the implications on data protection of the proposed amendments, ${ }^{283}$ the EDPS expresses several and significant concerns about the fact that the proposed amendments would also introduce other policy purposes-other than countering money laundering and terrorism financing-that do not

282. Proposal for a Directive of the European Parliament and of the Council Amending Directive (EU) 2015/849 on the Prevention of the Use of the Financial System for the Purposes of Money Laundering or Terrorist Financing and Amending Directive 2009/101/EC, COM (2016) 450 final (July 5, 2016). On November 8, 2016, the European Economic and Financial Affairs Council (known as "EcoFin"), met to discuss the European Commission's action plan against money laundering and terrorist financing activity. The focus was on the further amendments to the Fourth AML/CTF Directive, proposed in July 2016, when the action plan was published. As a result of those discussions and additional input received from some parliamentary committees, amendments to the original Directive adopted in 2015 have been proposed in a separate directive, referred to as the "Fifth" AML/CTF Directive. The new instrument seems to take a stricter approach than before to the problem of effectively countering money laundering and terrorism financing. In this respect, among other measures proposed, it focuses on new channels and modalities used to transfer illegal funds to the legal economy (e.g., virtual currencies, money exchange platforms, etc.). The proposal has not yet been agreed so no changes have been made to the 2015 Directive. It is understood that the European Presidency is aiming for agreement on the amendments proposed by the first months of 2017 so that negotiations with the European Parliament can start in the same year.

283. Eur. Data Prot. Supervisor, EDPS Opinion on a Commission Proposal Amending Directive (EU) 2015/849 and Directive 2009/101/EC: Access to Beneficial Ownership Information and Data Protection Implications (Feb. 2, 2017), https://edps.europa.eu/sites/edp/files/publication/17-02-02_opinion_ aml_en.pdf. 
seem clearly identified. ${ }^{284}$

According to the EDPS, the amendments, in particular, raise the question as to why certain forms of invasive personal data processing, acceptable in relation to AML/CTF goals, are necessary outside of those contexts and whether they are proportionate. As far as proportionality is concerned, the amendments would depart from the risk-based approach adopted by the current version of the AML/CTF Directive as the higher risk for anti-money-laundering, terrorism financing, and associated predicate offenses would not allow its timely detection and assessment. $^{285}$ Moreover, they also remove existing safeguards that would have granted a certain degree of proportionality, for example, in setting the conditions for FIUs access to information on financial transactions. ${ }^{286}$ Last, and most importantly, the amendments significantly broaden access to beneficial ownership information by both competent authorities and the public, as a policy tool to facilitate and optimize enforcement of tax obligations. The EDPS opines that this solution may give rise to significant and unnecessary risks for the individual rights to privacy and data protection. ${ }^{287}$ 